\title{
Program Araştırmalarının Konuları ve Gerekçelerinin Analizi
}

\author{
Analysis of the Subjects and Reasons of Curriculum Studies
}

Reha ATAŞ , Fen Bilimleri Öğretmeni, Nimet Alaattinoğlu Ortaokulu, Antalya/Türkiye, rehatas86@gmail.com

Okan BAYSAL , Sınıf Öğretmeni, Şehit Prof. Dr. İlhan Varank BILLSEM, Balıkesir/Türkiye, okanbbaysal@gmail.com

Nil AYKOL , Müdür Yardımcısı, Menderes Anadolu Lisesi, İzmir/Türkiye, aykolnil@gmail.com

Gülsen ÜNVER , Prof. Dr., Ege Üniversitesi, İzmir/Türkiye, gulsen.unver@ege.edu.tr

Ataş, R., Baysal, O., Aykol, N. ve Ünver, G. (2021). Program araştırmalarının konuları ve gerekçelerinin analizi. Batı Anadolu Eğitim Bilimleri Dergisi, 12 (1), 177-205.

Geliş tarihi: 21.01 .2021

Kabul tarihi: 09.05.2021

Yayımlanma tarihi: 28.06.2021

Öz. Bu çalışma 2010 - 2020 yılları arasında Türkiye'de ve yurt dışında program araştırmalarına ilişkin yayımlanmış makale ve doktora tezlerinin konularını, gerekçelerini ve eğilimlerini ortaya koyarak gelecekteki araştırmalara temel oluşturmayı amaçlamaktadır. Bu amaçla 65 makale; 26 doktora tezi olmak üzere toplam 91 araştırma incelenmiştir. Araştırmada betimsel içerik analizi yöntemi kullanılmıştır. Eğitim programları alanında yayımlanan araştırmalar konu, gerekçe, dergi seçimi, dünyanın farklı yerlerinden örneklemleri kapsaması, programın herhangi bir boyutunu içermesi, araştırma yönteminin izlenmesi ölçütleri dikkate alınarak çalışmaya dâhil edilmiştir. Analiz sonucunda politik etmenler, program - paydaş etkileşimi, program değerlendirme, toplumsal etmenler ve yeniden kavramsallaştırma temalarına ulaşılmıştır. Araştırma sonuçlarına göre, yurtdışındaki araştırmalar yönetim biçiminin ve politik gündemin etkisi, programa bağlılık, göçün etkisi, ırksal ve cinsel eşitlik konularında yoğunlaşmaktadır. Türkiye'de ise araştırmalar merkezi yaklaşım, programa bağlılık, örtük program, program değerlendirmede ölçüt geliştirme konularına ağırlık vermektedir. Bu sonuçlar doğrultusunda ilerideki program araştırmalarında sosyal adalet, dijital yeterlilikler, çok kültürlü eğitim, küresel salgının etkisiyle değişen öğretmenlik mesleki yeterlilik alanları, uzaktan eğitimin öğrenciler üzerindeki etkileri, öz düzenleme, ekoloji ve gölge program gibi konularına ağırlık verilmesi önerilmiştir.

Anahtar Kelimeler: Eğitim programları ve öğretim, Program çalışmaları, Betimsel içerik analizi, Programlar üzerine araştırma.

Abstract. This study aims to provide a basis for future research by revealing the subjects, reasons and tendencies of articles and dissertations related with curriculum studies published in Turkey and abroad from 2010 to 2020. For this purpose, a total of 91 studies consisting of 65 articles and 26 dissertations was analyzed. Descriptive content analysis method was used in the study. Research published in the field of Curriculum and Instruction was included by taking into consideration the criteria of subject, reasons, selection of journals, including samples from different parts of the world, involving a dimension of the curriculum and following the research method. As a result of the analysis, the themes of political factors, curriculum-stakeholder interaction, curriculum evaluation, social factors and reconceptualization were reached. According to the results of the study, research abroad focus on the effect of government and the political agenda, curriculum fidelity, the effect of immigration, 
racial and sexual equality. Research in Turkey focus on mainly centralized curriculum approach, curriculum fidelity, hidden curriculum and criteria development in curriculum evaluation. Based on these results, it is recommended to focus on the subjects such as social justice, digital competencies, multicultural education, teachers' professional competencies areas changing with the effect of pandemic, the effect of distance learning on students, self-regulation, ecology and shadow curriculum.

Keywords: Curriculum and instruction, Curriculum studies, Descriptive content analysis, Research on curricula. 


\section{Extended Abstract}

Introduction. Countries have been revising their education systems with the educational reforms as the roles assigned to education, scientific knowledge has been changing and transforming nowadays. One of the key factors performing educational reforms is curriculum. Curriculum shapes the education process and serves to grow up individuals needed in society by keeping up with the times. Individual and social research data lead to form education theory and policy. Since curriculum is an intermediary mechanism which transforms the theory and policy into practice, it is natural to determine its direction with the research (Varış, 1985). However, Curriculum research in Turkey is criticized for not attributing the research results (Mızıkacı and Gözütok, 2013; Yeşilpınar Uyar, 2017). At this point, it seems beneficial to increase research on curriculum studies.

There has been an increase in research examining tendencies in curriculum studies recently (Akdemir, Karameşe and Arslan, 2015; Demirhan İşcan and Hazır Bıkmaz, 2012; Gömleksiz and Bozpolat, 2013; Hazır Bıkmaz, Aksoy, Tatar and Altınyüzük, 2013; Kozikoğlu and Senemoğlu, 2015; Ozan and Köse, 2014; Özkal, 2020; SchregImann, 2016; Yeşilpınar Uyar, 2017). In this context, there has been research which studies postgraduate theses in Turkey and abroad in the field of Curriculum and Instruction and Curriculum Development (Demirhan İşcan and Hazır Bıkmaz, 2012); dissertations in the field of Curriculum and Instruction by determining a certain time period (Hazır Bıkmaz et al., 2013; Kozikoğlu and Senemoğlu, 2015; Özkal, 2020), dissertations and master's theses (Gömleksiz and Bozpolat, 2013); tendencies in the field of Curriculum and Instruction in terms of articles published domestically (Ozan and Köse, 2014); Curriculum Development research published in the Journal of Curriculum Inquiry (Akdemir, Karameşe and Arslan, 2015; Yeşilpınar Uyar, 2017) master's theses and dissertations in curriculum development (Schreglmann, 2016). It is understood that the research is limited in terms of detailed discussion on subjects and reasons of studies. There is some research examining the studies both in Turkey and abroad. Therefore, it is needed to study curriculum studies comprehensively.

In this study, it is aimed to provide a basis for future research by revealing the subjects, reasons and tendencies of articles and dissertations related with curriculum studies published in Turkey and abroad from 2010 to 2020 . The study is considered to be unique as it focuses on the content of the research examined and there is no other research investigating articles and dissertations in the last decade. It is noteworthy that the study determines the gaps in the field, making suggestions to the researchers regarding the required study subjects and providing information about the current situation of the field.

Method. In this study, a descriptive content analysis method which is one of the content analysis was adopted. 26 dissertations and 65 articles in Turkey and abroad which included samples from different countries, related with the curriculum and instruction, following the criteria by the research method from 2010 to 2020 were analyzed. Each research was recorded on the research classification form designed by researchers. Titles such as analysis code, author, title, sampling location, sample size, year of publication, data collection tools, research design/method and research topic got involved in research classification form. Whereas dissertations were coded as $\mathrm{T} 1, \mathrm{~T} 2$, articles were coded as $\mathrm{M} 1$, $\mathrm{M} 2$ in Microsoft Excel program in the study and they were associated with themes. The data analysis process was kept on by the researchers through document sharing, repeated readings and discussion meetings. An expert instructor in the field of Curriculum and Instruction examined the data set, codes and themes for the internal validity of the study. 
Results and Discussion. It is concluded that research abroad focuses on the effect of government and the political agenda, accountability, success evaluation policies, integrated curriculum, the effect of immigration, social justice, democracy education, environmental education, racial and sexual equality, critical pedagogy, cybernetics. It is concluded that research in Turkey focuses on centralized approach, education's aims, secularism, curriculum literacy, adaptation process of curriculum change, null curriculum, model development, developing criteria in curriculum development, curriculum theories. It is seen that researchers both Turkey and abroad inquire about internationalization / globalization, curriculum fidelity and hidden curriculum.

The concepts in the research are the subjects that are generally discussed in curriculum literature. For example, it is stated that policies need to update the curriculum (Hofman, Albert and Schnell, 2015) and success evaluation policies cause to create shadow curricula (Ventura and Jang, 2010). Education policies should be constituted by the values such as equality and justice (Şişman, 2006). Effective implementation of curriculum requires curriculum literacy. Hidden curriculum is more effective than formal curriculum (Posner, 2004). 21st century skills can be acquired through integrated curricula (Mohr and Welker, 2017). The important educational subjects of this century are discussions on environmental education and the function of the school in terms of reconceptualization.

Based on these results, it is recommended to focus on the subjects such as equality of opportunity in education, sexual and racial equality, multicultural education, social justice, digital competencies of teachers and parents, teachers' professional competencies areas changing with the effect of epidemic, shadow curriculum, the physical and psychological effect of distance learning on students, self-regulation, sustainable environment education for future research on curriculum studies. 


\section{Giriş}

Eğitim reformlarının önemli ögelerinden biri program çalışmalarıdır. Eğitim programlarının kendi içindeki ya da politik, ekonomik, toplumsal sorunlar reform hareketlerini doğurmaktadır. Eğitim programları reform sürecinden etkilenmekte ve reformun gerçekleşmesinde önemli bir rol üstlenmektedir. Ornstein ve Hunkins'in (2018) belirttikleri gibi, eğitim programındaki ve eğitim programına yönelik değişimler başta öğrenciler, öğretmenler ve aileler olmak üzere toplumun çok büyük bir bölümünü ilgilendirmektedir.

Yirminci yüzyılda, eğitim programı kavramına, sürecine ve bağlamına ilişkin Bobbitt'in (1918) Eğitim Programı (The Curriculum) adlı kitabı program geliştirmenin uzmanlık alanı olmasını etkilemiştir. Pinar (2010a) Amerika Birleşik Devletleri'ndeki (ABD) program çalışmalarını üç tarihsel aralık ile yapılandırmıştır. İlki 1918-1969 yılları arasında alanın doğuşu ve program geliştirmenin paradigmatik istikrara kavuşmasıdır. Bu anın doruk noktasını 1949 yılında program geliştirmenin kutsal kaynak kitabı olarak adlandırılan Ralph W. Tyler'ın Eğitim Programlarının ve Öğretimin Temel illkeleri (Basic Principles of Curriculum and Instruction) kitabı oluşturmaktadır. íkinci tarihsel aralık, alanın 1969 yılından 1980 yılına kadar devam eden program geliştirmeden program araştırmalarına alanın yeniden kavramsallaştırılmasıdır. Üçüncü tarihsel aralık ise, 1980 yııından 2000 yılına kadar disiplinlerarası akademik alan olarak programı anlamak etrafında paradigmatik olarak örgütlenmiştir.

$\mathrm{Bu}$ değişim süreci, Türkiye gibi, ABD’nin alanyazınından yararlanan ülkelerin program çalışmalarına ve araştırmalarına da yansımaktadır. Bu bağlamda John Dewey, Türkiye'nin eğitim sistemi hakkında bir rapor hazırlaması için 1924 yılında ülkeye davet edilmiştir. Yazdığı raporlarda, eğitimin finansmanı, bir eğitim planının oluşturulması ve yürütülmesi, okulların toplum merkezleri olarak geliştirilmesi, öğretmen eğitimi, okul sisteminin yeniden tanımlanması, okullarda sağlık ve hijyenin iyileştirilmesi konularında özel öneriler getirmiştir (Turan, 2000). II. Dünya Savaşı'ndan sonra ABD ile ilişkilerin gelişmesiyle Ford Vakfı ile Milli Eğitim Bakanlığı (MEB) arasında yapılan anlaşma sonucu, program çalışmalarını incelemek üzere ABD'ye uzmanlar gönderilmiştir (Varış, 1988). ABD'de eğitim alan Selahattin Ertürk ve Fatma Varış gibi bilim insanları EPÖ alanının Türkiye'de yeniden yapılanmasında önemli roller üstlenmişlerdir.

Türkiye'de pozitivist bilim felsefesinin eğitim araştırmalarındaki etkisiyle tarihsel ve felsefi çalışmalar program araştırmalarının dışında bırakılmıştır. Böylece, disiplinler arası araştırmalar sınırlı kalmış, program araştırmaları alanında ve aynı zamanda doktora çalışmalarında tarih ve felsefenin olmadığı bir alan ortaya çıkmıştır (Aktan, 2014). Eğitim alanında yaşanan bu değişimin ve dönüşümün, program araştırmaları açısından kaynak oluşturduğu düşünülmektedir. Özellikle boylamsal olarak planlanacak program araştırmalarının gerçekleştirilmesi, alanın tarihini irdeleyerek geleceğe ışık tutması açısından önemlidir.

Öte yandan, Schwab (1969), Pinar'ın (2010b) yeniden kavramsallaştırmanın başlangıcı olarak tanımladığı 1969 yılında, eğitim programı alanının can çekiştiğini ifade etmiştir. Ona göre, alan, mevcut yöntem ve ilkeler açısından çalışmalarına devam edemeyecek durumdadır; umutsuzca yeni ve daha etkili ilke ve yöntem arayışı içindedir ve program enerjilerinin büyük kısmı kuramdan uygulamaya aktarılırsa uyanma / canlanma olacaktır. Huebner (1976) ise alanın can çekişmekle kalmayıp öldüğünü belirtmiştir. Uygulamadan ziyade kurama bağı olan alan, yüzyıllar boyunca taşımaya çalıştığı artan ilgi çeşitliliği artık tek bir odakla bir arada tutulamayacağı için ölmüştür. Huebner (1976) alanın artık birliği ve bütünlüğü olmadığı için yeniden doğuş olamayacağını, köklerine geri dönerse ancak reenkarnasyonun mümkün olabileceğini ifade etmiştir. Bununla birlikte, Pinar'ın (2010b) tanımladığı üçüncü tarihsel aralıkta, alanın köklerine dönmek yerine programları anlama yönünde paradigma 
dönüşümü yaşandığı görülmektedir. Bu paradigma dönüşümünün günümüzde de devam ettiği söylenebilir. Bu süreçte, eğitim programı alanında çalışanların program araştırmalarının bulgularına intiyaçları vardır.

Bir araştırma alanı olarak eğitim programı çalışmaları, 1970'lerin sonlarında, alandaki bilim insanlarının sosyoekonomik sınıf, ırk, cinsiyet, yaş, dil, etnik köken, kültür, cinsel yönelim ve milliyet gibi etmenlere dayanan eğitim fırsatlarının eşitsizliğini ve adaletsizliğini ortaya çıkarmasıyla başlamıştır. Bilim insanları, bu gelişmelerle birlikte görevlerini sadece devletin ve kurumsal çıkarların desteklediği eşitsizlikleri devam ettiren eğitim programını daha verimli ve etkili bir şekilde geliştirmenin, tasarlamanın, uygulamanın ve değerlendirmenin araştırılması olarak görmemişlerdir. Bu nedenle, okullarda ve diğer kurumlarda haksız öğrenme deneyimlerine yol açan politika ve uygulamalarda açık ve net olan değerleri ve varsayımları incelemişler ve ortaya atmışlardır (Schubert, 2010). Program araştırmalarının bu yönüyle dönüştürücü paradigmadan etkilendiği söylenebilir. Nitekim Mertens (2015) dönüştürücü paradigmanın sosyal baskıya karşı durmak için, bir araştırmanın politika ve siyasal değişim gündemiyle iç içe durması gerektiğini belirtmektedir.

Program araştırmalarının çok uluslu yapısı, sadece alanı değil aynı zamanda disiplinlerarası alanları bilmeyi gerektirmektedir (Pinar, 2013). Bu durum eğitim programı çalışmalarında sosyoloji, antropoloji, psikoloji, ekonomi bilimi, siyaset bilimi, coğrafya, ekoloji, kültürel çalışmalar ve eğitim programının içinde bulunduğu bağlamların daha iyi anlaşılmasını sağlamayı amaçlamaktadır (Schubert, 2010). Apple (2010) bu durumu borçlanma sorunu olarak görmüş, eğitim programının en önemli görevlerinden birinin "ormanları ve ağaçları görmek" olduğunu belirterek disiplinlerarası bilgi ödünç verme işleminin çok dikkatli yapılmazsa ciddi zorluklar yaratacağından söz ederek alana genellikle yüzeysel düzeydeki anlayışlar aktarılırsa program çalışmalarında ciddi bir sorun oluşturacağını belirtmiştir. Bu yüzeysel etkileşimleri, farklı disiplinlerin program çalışmalarıyla bağlantılarını ayrıntılı olarak inceleyen araştırmalar önleyebilir.

Program araştırmalarının geleceği ile ilgili diğer bir nokta, geçmişin farklı yönlerinin ve doğasının bilinmesidir. Program araştırmacılarının gündeminde olan soruların birçoğu uzun bir geçmişe sahiptir (Apple, 2010). Schubert'in (2010) belirttiği gibi, eğitim programının tarihi, eğitim programı araştırmalarının tarihi bir sorgulama alanı olarak düşünülebilir.

Bireysel ve toplumsal araştırma verileri, eğitim kuramının ve politikasının oluşturulmasına öncülük etmektedir. Programlar bu kuram ve politikayı uygulamaya dönüştüren bir ara mekanizma olduğuna göre, yönünü bu araştırmalarla belirlemesi doğaldır (Varış, 1985). Buna rağmen, Türkiye'de program çalışmalarının, araştırma bulgularına dayandırılmaması sıklıkla eleştirilmektedir (Mızıkacı ve Gözütok, 2013; Yeşilpınar Uyar, 2017). Bu noktada, nitelikli program araştırmalarının artmasında yarar görülmektedir.

Türkiye'de program alanındaki araştırmaların niteliği de tartışma konusudur. EPÖ alanı bir bütün olarak düşünüldüğünde, öğrenme - öğretme sürecine (Bümen ve Aktan, 2014) öğrenme ortamına, eğitim teknolojisine ve program değerlendirmeye odaklanan birçok araştırmaya rastlanırken; cinsiyet ayrımı, ideoloji, program tarihi ve hükümetin rolü gibi konularla ilgilenilmediği gözlemlenmektedir (Aktan, 2014). Son yıllarda hazırlanan, yeniden kavramsallaştırmacılıkla ilgili doktora tezleri (ör., Korkmaz, 2016; Şiraz, 2020) program araştırmaları açısından umut vericidir. Program araştırmalarının niteliğini yükseltmek amacıyla gösterilen diğer bir çaba, Eğitim Programları ve Öğretim Derneği tarafından, 2011 yılından beri Uluslararası Eğitim Programları ve Öğretim Çalışmaları Dergisi'nin yayımlanmasıdır. Ancak dergide yayımlanan çalışmalar incelendiğinde, program araştırmalarına sınırlı düzeyde yer verildiği söylenebilir. 
Alanyazın incelendiğinde, özellikle son yıllarda program araştırmalarındaki eğilimleri inceleyen çalışmalarda artış görülmektedir (Akdemir, Karameşe ve Arslan, 2015; Demirhan Işcan ve Hazır Bıkmaz, 2012; Gömleksiz ve Bozpolat, 2013; Hazır Bıkmaz, Aksoy, Tatar ve Altınyüzük, 2013; Kozikoğlu ve Senemoğlu, 2015; Ozan ve Köse, 2014; Özkal, 2020; SchregImann, 2016; Yeşilpınar Uyar, 2017). Bu bağlamda, EPÖ ya da Eğitimde Program Geliştirme alanında, Türkiye'de ve yurt dışındaki mevcut lisansüstü eğitim programlarının (Demirhan İşcan ve Hazır Bıkmaz, 2012); belli bir zaman aralığı belirlenerek EPÖ alanında yapılan doktora tezlerinin (Hazır Bıkmaz vd., 2013; Kozikoğlu ve Senemoğlu, 2015; Özkal, 2020), doktora ve yüksek lisans tezlerinin (Gömleksiz ve Bozpolat, 2013); yurt içinde yayınlanan makaleler açısından EPÖ alanındaki eğilimlerin (Ozan ve Köse, 2014); yurt dışında yayımlanan Curriculum Inquiry dergisi bağlamında program geliştirme araştırmalarının (Akdemir vd., 2015; Yeşilpınar Uyar, 2017) eğitimde program geliştirme özelinde yüksek lisans ve doktora tezlerinin (Schregımann, 2016) incelendiği çalışmalar bulunmaktadır. Bu çalışmalarda program araştırmalarının genellikle araştırma konusu, araştırma modeli, veri toplama araçları, veri analiz teknikleri değişkenleri açısından incelendiği belirlenmiştir. Hazır Bıkmaz ve diğerlerinin (2013) 1974 - 2009 yılları arasında, Kozikoğlu ve Senemoğlu'nun (2015) 2009 - 2014 yılları arasında ve Özkal'ın (2020) 2015 - 2019 yılları arasında EPÖ alanındaki doktora tezlerindeki araştırma eğilimlerini belirledikleri çalışmaların birbirini tamamladıkları söylenebilir. Bu çalışmalarda, öğretme-öğrenme yaklaşımları, yöntemleri, teknikleri, öğretmen eğitimi ve program değerlendirme konularının çalışıldığı belirlenmiştir. Özetle, program araştırmalarını inceleyen çalışmalar araştırma konularının ve gerekçelerinin ayrıntılı tartışılması açısından sınırı bulunmuştur. Yurtiçindeki ve yurtdışındaki program araştırmalarını birlikte inceleyen çalışmalar da oldukça az sayıdadır. Bu nedenle, program araştırmalarını daha geniş kapsamlı bir incelemeye ihtiyaç duyulmuştur.

Bu çalışmanın amacı, 2010 ve 2020 yılları arasında Türkiye'de ve yurt dışında program araştırmalarına ilişkin yayımlanmış makale ve doktora tezlerinin konularını, gerekçelerini ve eğilimlerini ortaya koyarak, ilerideki araştırmalar için temel oluşturmaktır. Bu çalışma, yurt içinde ve yurt dışında tez ya da makale olarak yayımlanmış araştırmaları kapsaması nedeniyle geniş bir bakış açısı sunabilir. Çalışmanın, program araştırmalarının içeriğine odaklanmış olması da özgünlüğünü sağlayabilir. Çalışmanın bulgularının program araştırmalarındaki eğilimler ve boşluklar açısından araştırmacılara yol gösterebileceği ve bu sayede alana katkı sağlayabileceği düşünülmektedir. Belirlenen amaçtan hareketle, araştırma soruları şu şekilde oluşturulmuştur: 2010 - 2020 yılları arasında farklı ülkelerde gerçekleştirilen:

1. Program araştırmalarında çalışılan konular / problemler nelerdir?

2. Program araştırmalarının raporlarında, üzerinde çalışılan konuların / problemlerin, gerekçeleri nasıl açıklanmaktadır?

\section{Yöntem}

Bu çalışmada, içerik analizi türlerinden betimsel içerik analizi yöntemi kullanılarak 2010 - 2020 yılları arasında eğitim programları alanında belirli ölçütler dâhilinde seçilen yurt içinde ve yurt dışında hazırlanmış tez ve makaleler incelenmiştir. Betimsel içerik analizinde, nitel ve nicel araştırmalar bir araya getirilerek incelenmekte ve alandaki genel eğilim ortaya çıkarılmaktadır (Cohen, Manion ve Morrison, 2007). Bu sayede, ilgili alanda çalışma yapmak isteyen araştırmacılara, genel yönelimlerle ilgili bilgi sunulmaktadır (Selçuk, Palancı, Kandemir ve Dündar, 2014). Bu çalışmada, son 10 yıl içinde eğitim programları alanında yapılan 91 araştırma incelenmiş ve araştırmalar konularına göre kodlanmıştır. Benzer kodlar aynı temalar altında birleştirilerek eğitim programları alanındaki eğilimler ortaya çıkarıımıştır. 


\section{Araştırmaların Analize Dâhil Edilme Ölçütleri ve Verilerin Toplanması}

EPÖ alanındaki araştırma eğilimlerini ortaya çıkarmak amacıyla, öncelikle çalışmaya dâhil edilecek araştırmaların seçimi için makalenin / tezin yılı, doktora tezi ve makale olması, dergi seçimi, dünyanın farklı yerlerinden örneklemleri kapsaması, programın herhangi bir boyutunu içermesi ve araştırma yöntemi ölçütleri belirlenmiştir. Bu ölçütlere göre makale ve tezler taranarak, çalışmaya dâhil edilmiştir.

Çalışmanın kapsayacağı yıllar belirlenirken, alanyazındaki program araştırmalarının analiz edildiği çalışmalar incelenmiştir. Bu çalışmalarda, Akdemir vd. (2014) 2005 - 2013, Hazır Bıkmaz vd. (2013) 1974 - 2009, Kurt ve Erdoğan (2015) 2004 - 2013, Ozan ve Köse (2014) 2007 - 2011 ve Yeşilpınar Uyar (2017) 2002 - 2015 yılları arasındaki program araştırmalarının eğilimlerini ortaya çıkarmışlardır. Buna göre, son 10 yııı kapsayan program eğilimlerini gösteren araştırma bulunmamaktadır. Bu nedenle, güncel araştırmaların analizinin eğitim programları alanına yön verebileceği düşünülmüş ve çalışmaya 2010 - 2020 yılları arasındaki program araştırmaları dâhil edilmiştir.

Genel eğilimlerin kapsamlı bir çalışmayla yürütülebileceği gerekçesiyle, çalışmaya doktora tezi ve makaleler dâhil edilmiştir. Bu kapsamda, 2010 - 2020 yılları arasında YÖK Ulusal Tez Merkezi'nde yayımlanan EPÖ alanındaki doktora tezleri taranmıştır. Yurt dışı doktora tezlerine ise Proquest veri tabanı aracılığıyla ulaşımıştır. Dergilerin seçiminde ise, yurt içinde eğitim alanında yayınlanan tüm dergiler dâhil edilmiştir. Yurt dışındaki dergilerin seçiminde etki faktörü, alıntılama oranı, , $\mathrm{H}$-indeks değeri ve $Q$ değeri dikkate alınmıştır. Buna göre seçilen Journal of Curriculum Studies dergisinin; etki faktörü 1.484 , alıntılama oranı $2.9, \mathrm{H}$-indeks değeri 54 ve Q1 çeyreğinde yer almaktadır. Journal of Curriculum Inquiry dergisinin; etki faktörü 1111, alıntılama oranı 1. 8, H-indeks değeri 36 ve Q1 çeyreğinde yer almaktadır.

Uluslararası program eğilimlerini ortaya çıkarmak amacıyla, çalışmaya farklı ülkelerde yürütülen araştırmalar dâhil edilmiştir. Çalışmada incelenen makale ve tezlerin 39'u Türkiye'de, 24'ü ABD'de, 5'i Çin, 5'i Kanada'da, 4'ü Avustralya'da, 2'si Güney Afrika, 2'si Güney Kore'de, 2'si Finlandiya'da, 1'i Fransa'da, 1'i Almanya'da, 1'i İrlanda'da, 1'i Sırbistan'da, 1'i Yeni Zelanda'da, 1'i Endonezya'da, 1'i Pakistan'da, 1'i Meksika'da, 1'i İsveç'te, 1'i İngiltere'de ve 1'i Estonya'da gerçekleştirilmiştir. Bazı çalışmaların birden fazla ülkede yürütüldüğü görülmüştür. Böylece, Avrupa, Asya ve Uzak Doğu'da yer alan ülkelerdeki program çalışmalarının alandaki etkileri ortaya çıkarılmaya çalışılmıştır.

Bu çalışmada program alanındaki genel eğilimleri ortaya çıkarmak amaçlandığından, belli bir branşı kapsayan, bir alana yönelik araştırmalar çalışmaya dâhil edilmemiştir. Çalışmanın ilk aşamasında 104 araştırma ile inceleme başlatılmış, ancak eğitim programları alanına girmeyen, program odaklı çalışımayan öğretmen eğitimi araştırmaları çalışmadan çıkarılmıştır. Ayrıca, oyun temelli program konulu araştırma temalara doğrudan girmediği anlaşıldığından çalışmanın kapsamı dışına alınmıştır. Sonuçta, çalışma 91 araştırma üzerinde gerçekleştirilmiştir. Çalışmaya dâhil edilen araştırmaların tümü genel eğitim programları çalışmalarını kapsamaktadır. Derleme, doküman analizi, kitap incelemesi türündeki makale ya da tezlerin çalışmaya dâhil edilmemesi ölçütü belirlenmiştir. Ancak, program alanında önemli bulguları içeren ve alana önemli katkı getirebileceği düşünülen yurt içi ve yurt dışı doküman analizi ve derleme araştırmaları çalışmaya dâhil edilmiştir. 
Çalışmaya dâhil edilecek makale ve tezlerin ölçütleri belirlendikten sonra, araştırmacılar tarafından "Araştırma Sınıflama Formu" oluşturulmuş ve her araştırmanın bilgileri bu forma kaydedilmiştir. Araştırma Sınıflama Formunda; analiz kodu, yazar, başlık, örneklem yeri, örneklem büyüklüğü, yayım yılı, veri toplama araçları, araştırma deseni / yöntemi ve araştırma konusu başıkları yer almıştır. Bu form, araştırmaların yöntemsel özelliklerini betimlemek amacıyla kullanılmıştır.

Bu çalışmada $26^{\prime}$ si yurtiçinde ve 39'u yurtdışında yayımlanmış toplam 65 makale; 13'ü yurtiçinde ve $13^{\prime}$ ü yurt dışında yayımlanan toplam 26 doktora tezi incelenmiştir. Çalışmada, $5^{\prime} i$ nicel, 77'si nitel, 9'u karma yöntemle oluşturulmuş 91 araştırma yer almaktadır. Yurt içinde yayımlanan makalelerin 9'u durum çalışması, 6'sı doküman analizi, 5'i olgubilim, 2'si ölçek geliştirme, 1'i Delphi tekniği, $1^{\prime} i$ betimsel tarama, $1^{\prime} i$ tarama ve $1^{\prime} i$ karma desendedir. Yurt dışı makalelerin $24^{\prime}$ ü durum çalışması, 4'ü olgu bilim, 3'ü gömülü teori, 2'si etnografik araştırma, 2'si anlatı araştırması, 1'i eleştirel söylem analizi, $1^{\prime} i$ meta analiz, $1^{\prime} i$ derleme ve $1^{\prime} i$ karma desen ile oluşturulduğu görülmüştür. Yurtiçi tezlerin 5'i karma desen, 2'si olgubilim, 2'si durum çalışması, 1'i nitele dayalı tarama, 1'i temel nitel desen, $1^{\prime} i$ kuramsal inceleme ve $1^{\prime} i$ betimsel modelde nitel araştırma kullanılarak hazırlanmıştır. Yurt dışı tezlerin ise 5'i durum çalışması, 2'si olgubilim, 2'si karma, 1'i eleştirel söylem analizi, 1'i kuram oluşturma, $1^{\prime} i$ etnografik araştırma ve $1^{\prime} i$ derleme çalışmasıdır.

Çalışmaya dâhil edilen araştırmalar, excel dosyasında makaleler için M1, M2 şeklinde; tezler için T1, T2 şeklinde isimlendirilerek açıklama bölümüne çalışmanın konusu, amacı ve gerekçesi yazılmıştır. Bu dosya, çalışmanın bir bakıma veri setini oluşturmuştur. Bununla birlikte çalışmanın sonuna kadar, gerektiğinde ana metinler yeniden okunmuş ve incelenmiştir. Excel dosyasında araştırmaların konuları ve gerekçeleri dikkate alınarak kodlamalar yapıımıştır. Bu işlem dört araştırmacı tarafından, dokümanlar paylaşılarak gerçekleştirilmiştir. Analiz sürecinde bütün araştırmacılar kodlamalarla ilgili tartışma toplantıları yapmışlardır. Araştırma ekibi, analiz dosyası üzerinde son bir tartışma toplantısı yaparak, bazı araştırma kodlarının alt temalarının ya da temalarının değiştirilmesi, araştırmaya ilişkin daha çok açıklamaya yer verilmesi gibi düzenlemeler yapmıştır. Sonuçta Tablo 1'de yer alan altı temaya ulaşılmıştır.

\section{Geçerlik ve Güvenirlik}

Shenton (2004) kodlayıcıların, kodlama sürecinde çelişkili ya da emin olunmayan kodlar üzerinde tartışarak bulguların iç tutarııı̆ını yükseltmelerini önermiştir. Bu çalışmada da kodlayıcılar analiz sürecinde ihtiyaç duydukları zamanlarda toplantı düzenleyerek belirsizlik ya da ikilem yaşanan kodlar üzerinde tartışmışlardır. Yıldırım ve Şimşek'e (2018) göre uzman incelemesi, araştırma konusu hakkında genel bilgiye sahip uzmanlaşmış kişilerden araştırmayı çeşitli boyutlardan incelemesinin istenmesi iç geçerliliği artırmaktadır. Bu çalışmanın iç geçerliliğini artırmak amacıyla, eğitim programları alanında uzman bir öğretim üyesi veri setini, kod ve temaları incelemiş ve teyit etmiştir. Nitel araştırmalarda; toplanan verilerin ayrıntılı olarak sunulması (Le Compte ve Goetz, 1982) ve sonuçlara ulaşma sürecinin ayrıntılı bir şekilde açıklanması (Yıldırım ve Şimşek, 2018) geçerliğin önemli ölçütleri arasında sayılmaktadır. Bu çalışmada, verilerin toplanması, veri toplama ölçütleri ve veri analizi aşamalarının ayrıntılı bir şekilde sunulmasına özen gösterilmiştir.

\section{Bulgular}

Türkiye'deki ve yurtdışındaki program araştırmalarının konuları ve gerekçeleri bakımından analizi sonucunda politik etmenler, program - paydaş etkileşimi, program türleri, program değerlendirme, toplumsal etmenler ve yeniden kavramsallaştırma temalarına ulaşılmıştır. Bu temalar 
ve alt temalara giren Türkiye'deki ve yurtdışındaki program araştırmalarının frekansları Tablo 1'de sunulmuştur. 
Tablo 1.

Yurtiçindeki ve yurtdışındaki program araştırmalarının konularına göre dağııımı

\begin{tabular}{|c|c|c|c|}
\hline \multirow[t]{2}{*}{ Araştırma Konuları } & $\begin{array}{r}\begin{array}{r}\text { Türkiye'deki Program } \\
\text { Araştırmaları }\end{array} \\
\end{array}$ & $\begin{array}{r}\text { Yurtdışındaki Program } \\
\text { Araştırmaları }\end{array}$ & Toplam \\
\hline & $f$ & $f$ & $f$ \\
\hline \multicolumn{4}{|l|}{ Politik Etmenler } \\
\hline Yönetim biçiminin etkisi & 2 & 4 & 6 \\
\hline Politik gündemin etkisi & - & 5 & 5 \\
\hline Hesap verebilirlik & - & 1 & 1 \\
\hline Başarıyı değerlendirme & - & 2 & 2 \\
\hline \multicolumn{4}{|l|}{ Politikaları } \\
\hline Uluslararasılaşma / küreselleşme & 3 & 3 & 6 \\
\hline Merkezi yaklaşım & 8 & 1 & 9 \\
\hline Uzak hedefler & 1 & - & 1 \\
\hline Laiklik & 1 & - & 1 \\
\hline Toplam & 15 & 16 & 31 \\
\hline \multicolumn{4}{|l|}{ Program - Paydaş Etkileşimi } \\
\hline Programa bağlıık & 5 & 6 & 11 \\
\hline Program okuryazarlığı & 3 & - & 3 \\
\hline $\begin{array}{l}\text { Program değişikliğine uyum } \\
\text { süreci }\end{array}$ & 2 & 4 & 6 \\
\hline Toplam & 10 & 10 & 20 \\
\hline \multicolumn{4}{|l|}{ Program Türleri } \\
\hline Örtük program & 6 & - & 6 \\
\hline İhmal edilen program & 1 & - & 1 \\
\hline Bütünleşik program & - & 1 & 1 \\
\hline Toplam & 7 & 1 & 8 \\
\hline \multicolumn{4}{|l|}{ Program Değerlendirme } \\
\hline Model geliştirme & 1 & - & 1 \\
\hline $\begin{array}{l}\text { Standart oluşturma / ölçüt } \\
\text { geliştirme }\end{array}$ & 4 & - & 4 \\
\hline Toplam & 5 & - & 5 \\
\hline \multicolumn{4}{|l|}{ Toplumsal Etmenler } \\
\hline Göçün etkisi & - & 7 & 7 \\
\hline Sosyal adalet & - & 4 & 4 \\
\hline Demokrasi eğitimi & - & 1 & 1 \\
\hline Çevre eğitimi & - & 1 & 1 \\
\hline Cinsel eşitlik & - & 3 & 3 \\
\hline Irksal eşitlik & - & 4 & 4 \\
\hline Toplam & - & 20 & 20 \\
\hline \multicolumn{4}{|l|}{ Yeniden Kavramsallaştırma } \\
\hline Eleştirel pedagoji & & 3 & 3 \\
\hline Sibernetik & - & 1 & 1 \\
\hline Politik metin olarak incelenmesi & 3 & & 3 \\
\hline Toplam & 3 & 4 & 7 \\
\hline Genel Toplam & 40 & 51 & 91 \\
\hline
\end{tabular}

\section{Politik Etmenler}

Tablo 1'de görüldüğü gibi, politik etmenler teması kapsamında yönetim biçiminin etkisini araştıran çalışmalar bulunmaktadır. Örneğin, Yang ve Li (2018a) Honkong ve Shenzen bölgelerinde kapitalist ve sosyalist düzenin program ideolojilerine, Mølstad (2015) Finlandiya ve Norveç'teki ulusal programların yerel programlara, Mansoor ve Malik (2016) Pakistan'daki sömürgeci anlayışın İngiliz 
edebiyatı derslerinde siyasal konuların oluşturulmasına etkisini belirlemeyi amaçlamışlardır. Zhao (2020) ise Çin'de Batı́nın (Ekonomik Kalkınma ve İşbirliği Örgütü ülkeleri) politika anlayışı ile hazırlanan suyang (yeterlik) reformunun oluşturduğu bilgiyi ortaya çıkarmaya çalışmıştır. Mala (2011) Türkiye'de geçmişten günümüze ilköğretimde eğitime kaynaklık eden politik anlayışların sonuçlarını belirleme ve bu sonuçların ilköğretim programlarının geliştirilmesine katkı sağlama gerekçesiyle Cumhuriyet dönemi ilköğretim programlarını, program öğeleri açısından incelemiştir. İşeri (2011) program teorisi alanındaki yaklaşım ve modellerin kavramsal içeriklerini, metodolojisini ve enstrümanlarını anlayabilme gerekçesiyle program teorisinin eğitim felsefesi ve sosyolojisi ile ideoloji kuramları açısından düşünsel, ideolojik temellerini ortaya koyarak program teorisi önerisi getirmiştir.

Politik etmenler teması kapsamında politik gündemin etkisini araştıran çalışmalarda; Garrett (2020), Amerika' da silahlı şiddetin yarattığı politik gündem ve bu sebeple sınıf içinde oluşan tartışmalar nedeniyle, öğrencilerin duygusal ilişkilerine yansıma durumunu problem edinmiştir. Ito, Soep, Vilenchik, Thompson ve Zimmerman (2020) gençlerin kişisel ilgilerine, kimliklerine bağlı olarak dijital ortamlarda oluşturdukları toplulukların bir politikayı desteklediği gerekçesiyle oluşturulan yeni politika söylemlerini ortaya çıkarmayı, program çalışmaları için önemli görmüşlerdir. Wu (2012), kalite eğitimi adı verilen Suzhi Jiayou reformu kapsamında, pedagoji uygulamalarıla kalitenin yeniden tanımlanmasını ve ideal insan yetiştirmedeki yerini ortaya çıkarmayı amaçlamıştır. Sosyal koşulların, siyasi uyumların, kurumsal düzenlemelerin, liderliğin, medyanın ve retoriğin ulusal program reformunu nasıl şekillendirdiğini inceleyen Jang (2017), 2015 Ulusal Eğitim Programı Reformunu politik bağlamda irdelemiştir. Akrom (2015) politikanın okul düzeyinde nasıl yorumlandığına ilişkin bilgi tabanının önemli ölçüde oluşturulmadığı gerekçesiyle yerel paydaşların okul tabanlı program geliştirmeye katılımını incelemiştir.

Politik etmenler teması kapsamında hesap verebilirliği konu edinen Mathou (2018), hesap verebilirlik ve performans değerlendirmeye bağı olarak, eğitimi yeniden bağlamsallaştırdığı gerekçesiyle, çağdaş program politikalarının mesleki kimliği şekillendirmedeki etkisini incelemiştir. Başarıyı değerlendirme politikalarını konu edinen araştırmalarda; Yoon (2016) Vancouver' da alternatif program sunan devlet okullarına sınavla giren öğrencilerin statü farklılığı oluşturduğu gerekçesiyle yetenekli olarak algılanan elit öğrencilerin belirlenmesinin etkilerini ele almıştır. Dutro ve Selland (2012), Amerika'da sınav odaklı eğitim reformunu çocukların nasıl anlamlandırdığına yönelik az araştırma olduğu gerekçesiyle öğrencilerin testlere yönelik duygularını, puana yönelik algılarını ve yeterlik ile ilgili varsayımlarını belirlemeyi araştırma konusu edinmişlerdir.

Politik etmenler temasındaki uluslarasılaşma / küreselleşme konulu araştırmalarda; Pantić ve Wubbels (2012), Sırbistan'da Bologna süreciyle beraber öğretmen eğitimi programlarında yapılan yeterlilik odaklı değişikliklerin, öğretmen adaylarının yeterlik algılarına etkilerini araştırma problemi olarak nitelendirmişlerdir. Donald-Whitney (2019) eğitim programını yönetmenin zor bir süreç olduğu gerekçesiyle çok kampüslü bir üniversite / kolej bölgesindeki eğitim programı yönetim sistemlerini incelemiştir. Whitaker (2012) küresel ölçekte bir program modelinin amaç ve tasarımını belirlemek gerekçesiyle, programın kapsamlı bir tanımını ve küresel temalı bir ilkokuldaki uygulama sürecini incelemiştir. Uluslararasılaşma kapsamında, Çapuk (2014) EPÖ alanı için yüksek lisans ve doktora düzeyinde "çerçeve program" oluşturma gerekçesi ile Türkiye ve $A B D$ 'deki lisansüstü programları karşılaştırılmıştır. Şahin, Ökmen, Boyacı, Kılıç ve Adıgüzel (2018) küreselleşmenin etkisini arttıran Bologna sürecine uyum sağlayacak EPÖ yüksek lisans öğretim programları için ihtiyaçların belirlenmesinin önemli olduğu gerekçesiyle intiyaç analizi çalışması yapmışlardır. Keller (2015) ise uluslararası eğitim anlayışının artması gerektiği inancıyla, uluslararası okullardaki topluluklarda yer alan bireylerin uluslararası eğitime bakış açılarını incelemiştir.

Tablo 1'de, politik etmenler kapsamında, yurtdışında tek araştırma tespit edilmiştir. Yang ve Li (2018b) Güney Çin bölgesinde okul temelli program geliştirme çalışmalarını sosyokültürel ve tarihsel 
perspektiften inceleme gerekçesiyle, üç okulöncesi eğitim kurumunda yürütülen çalışmaları irdelemiştir. Türkiye'deki araştırmaların program çalışmalarında izlenen merkezi yaklaşım üzerine yoğunlaştığı dikkati çekmektedir. Merkezi yaklaşım ile yürütülen programların yerel düzeydeki farklılıklar nedeniyle uygulamada sorunlara neden olduğu, okul temelli program geliştirme süreçlerinin tespit edilmesi, paydaş düşüncelerinin ve toplumsal intiyaçların belirlenmesi gerekçesiyle araştırmalar (Bay, Vural, Kahramanoğlu ve Aydın Aşk, 2016; Kaya, Çetin ve Yıldırım, 2012) yapılmıştır. Bu araştırmalarda okul temelli program geliştirme süreçlerinin nasıl olması gerektiğine ilişkin lisans programlarına yönelik öğrenci görüşleri (Bay vd., 2016; Mızıkacı, Göktunalı, Aktaş, Görür, Kızıl ve Çınar, 2019) ve okul temelli değerler eğitimi programı geliştirme çalışmaları (Özyurt, Demir ve Bay, 2016) incelenmiştir. Alana özgü öğretim programı geliştirme çalışmalarına katkı sağlamak ve programın etkililiğini artırmak gerekçesiyle Demiralp (2017) farklı öğretim kademelerinde uygulanan coğrafya dersi merkezi program tasarımını karşılaştırmıştır. Yücel, Dimici, Yıldız ve Bümen (2017) ise programların verimliliğini artırmak için incelenmesinin önemli olduğu gerekçesi ile son 15 yılda yayımlanan İngilizce öğretim programlarını analiz etmişlerdir. Merkezi programlardan sosyal bilgiler öğretim programını yenilenmiş taksonomiye göre inceleyen Büyükalan-Filiz ve Baysal (2019) araştırmalarına gerekçe olarak taksonominin üst basamaklarını dikkate almadan tasarlanan programların; öğrencilerin problem çözme becerilerini, düşüncelerini ifade etmelerini ve bir ürüne ilişkin karar vermelerini engelleyebileceğini belirtmişlerdir. Yurdakul ise (2015) öğretmenlerin programı algılama biçimlerinin öğretim süreçlerini etkilediği ve program geliştirme bağlamında önemli bilgiler barındırdığı gerekçesiyle öğretmenlerin ilköğretim programı algılarını incelemiştir.

Politik etmenler temasında, Türkiye'de çalışılan diğer araştırma konusu ülkelerin uzak hedefleridir. Örneğin, Özkan (2018), 1923 - 1946 tek parti döneminde eğitime ilişkin siyasi ilkelerin ülkenin uzak hedeflerinin yapıtaşı olduğunu ve programların bu çerçevede şekillenmesi gerektiğini düşünmektedir. Bu düşünceyi temel alarak tek parti dönemindeki uzak hedeflerin programlara yansımalarını incelemiştir. Türkiye'deki program araştırmalarında laiklik bağlamında din eğitiminin de konu edildiği görülmüştür. Arsal (2014), çok kültürlülük ve laiklik açısından din kültürü öğretim programlarını incelemiştir. Söz konusu araştırmada, Avrupa Birliği uyum yasası yükümlülüklerinin yerine getirilmesi gerekçesiyle din eğitimine yönelik öneriler sunulmuştur.

\section{Program ve Paydaş Etkileşimi}

Tablo 1'de görüldüğü gibi, program - paydaş etkileşimi teması kapsamında, programa bağlılı̆ı inceleyen araştırmalar vardır. Örneğin, Toledo (2020) öğretmenlerin toplumsal vatandaşlık konusunda yetersiz olduğu gerekçesiyle, toplumsal vatandaşlıkla ilgili konuları programa uyarlama biçimlerini araştırmıştır. Hedges, Cullen ve Jordan (2011), yaşamın ilk yıllarındaki programların kaynağının çocuğun ilgi alanı olduğunu temele alarak öğretmenlerin programdaki bu etkileşime yönelik ilgilerini araştırmayı önemli görmüşlerdir. Erss, Kalmus, Tero ve Autio (2016), öğretmenlerin neo-liberal eğitim reformları çerçevesinde programı uygulama ve yorumlama biçimlerinin farklılık gösterebileceği sayıltısıyla, mesleki özerkliklerini geçmişteki deneyimlerine bağlı olarak betimlemişlerdir. Scholtz (2020) ise, öğretim elemanlarının resmi programdaki sorumluluklarını yerine getirmelerini etik bir mesele olarak görmüş ve öğretim uygulamalarını geliştirmek için yaptıkları çalışmaları etik açıdan incelemişlerdir. Fahey (2012) yükseköğretim kurumlarının, geleceğin liderlerini, karışık ve küresel sorunlara çözüm üretecek bireyleri yetiştirmesinin önemli olduğu gerekçesiyle, kurumun eylem kapasitesi ve program amacı arasındaki uyumu ortaya çıkarmayı amaçlamıştır. Fenwick (2012) ise, standart temelli reformların, en düşük düzeydeki başarıya odaklandığı ve öğrencilerin performansını sınırladığını gerekçe göstererek, öğretmenlerin programı uygulamadaki farklııklarına odaklanmıştır. 
Programa bağlılığı inceleyen Türkiye'deki araştırmalarda, programların konu merkezli tasarıma göre hazırlandığı (Karaman ve Bakaç, 2018) öğretmenin sınıf içindeki uygulamalarının programı ne kadar yansıttığı yani programa bağlıı̆̆ının (Dikbayır ve Bümen, 2016) özgüven, mesleki yeterlilik gibi faktörlerden etkilendiği belirtilmiştir. Bu problemin incelenmeye değer görülmesinin nedenleri olarak eğitim reformlarının hayata geçirilmesinde öğretim uygulamalarının önemli olduğu ve reformların maliyetlerini karşılaması gerektiği vurgulanmıştır (Bümen ve Yazıcılar, 2020; Dikbayır ve Bümen, 2016). Programa bağlılık, programların aslına sadık (Bümen, Çakar ve Yıldız, 2014) kalınarak uygulanması, programlardan istenen verimin alınması (Yeşilyurt, 2019), program geliştirme çalışmalarına katkı sağlaması (Ünver ve Erdamar, 2015) açısından önemli görülmüş ve araştırmacılar tarafından konu olarak ele alınmıştır.

Program - paydaş etkileşimini program okuryazarlığı açısından incelemeye değer gören araştırmalarda (Bolat, 2017; Kahramanoğlu, 2019) öğretmen niteliği vurgusu yapılmış, öğretmenlerin ve öğretmen adaylarının program okuryazarı olmasının mesleki açıdan zorunlu olduğu (Özer ve Alkan, 2017) belirtilmiştir. Bolat (2017) ve Kahramanoğlu (2019) program okuryazarı olmayan öğretmenlerin, programın amaçlarından ve uygulama esaslarından farklı öğrenme öğretme süreçleri oluşturabileceği gerekçesiyle Eğitim ve Öğretim Programı Okuryazarlık Ölçeği geliştirmişlerdir.

Program - paydaş etkileşimi kapsamında program değişikliğine uyumu inceleyen Dixon Mcinerney (2019) sınıftaki öğrenci gereksinimlerinin karşılanmasının önemli olduğu düşüncesiyle $A B D$ 'de öğretmenlerin program uyarlama / ayarlamaları konusunda ne derece yetkilendirildiklerine ilişkin algılarını incelemiştir. Burti (2010) program uyarlamalarının öğrenci performansına etkisini belirlemek gerekçesiyle Cebir I programının New Jersey Temel Program İçerik Standartları ve Amerikan Diploma Projesi'nin Ders Sonu Sınavı ile uyumunu incelemiştir. Jarvis (2012) program uygulamalarındaki farklılıkları belirlemek amacıyla program değişikliği sürecini fakülte yükseköğretim açısından incelemiştir. Thompson (2019), Uluslararası Bakalorya İlk Yıllar Programı okulunda çok yönlü düşünebilmek için tutku, niyet, modelleme ve yansıtma temalarını içeren bir program geliştirme, uygulama ve değerlendirme çalışması yapmıştır.

Program - paydaş etkileşimi temasına giren program değişikliğine uyum sürecini inceleyen Türkiye'deki araştırmalarda Dikbayır (2018) lise matematik dersi için tasarlanan, uygulanan, ölçülen programın uyumunu, Tokgöz (2013) ise ilköğretim sosyal bilgiler program tasarısının öğretmenler tarafından algılanış biçimi ve uygulamaya dönüştürülmesindeki öğretmen deneyimlerini incelemiştir. Bu araştırmalar için; tasarlanan, uygulanan ve ölçülen programın birlikte incelenmesi ile öğretmenlerin program uygulamalarına ilişkin ayrıntılı bilgi elde edilmesi (Dikbayır, 2018) ve kuramın uygulamadaki değişim sürecini anlamanın (Tokgöz, 2013) önemi gerekçe olarak sunulmuştur.

\section{Program Türleri}

Tablo 1'deki diğer bir tema olan program türleri kapsamında örtük programı konu edinen araştırmalarda, resmi eğitimi destekleyen örtük programların öğretmenler tarafından daha sık ele alındığı bu nedenle öğretmenlerin örtük program algılarının belirlenmesinin önemli olduğu ifade edilebilir. Araştırmalarda kavrama ilişkin kuramsal çerçeve çizildiği, örtük program bağlamında değerlendirme süreçlerinin incelendiği (Akbulut ve Aslan, 2016) ve uygulamaların ortaya çıkarıldığı (Tuncel ve Demirel, 2018) tespit edilmiştir. Çengel ve Türkoğlu (2016) ise öğrenci başarısını etkileyen sosyal örüntülerin anlaşılması gerekçesiyle sosyoekonomik düzey açısından alt başarı grubunu temsil eden meslek lisesi öğretmenlerinin örtük program davranışlarının incelenmesini anlamlı bulmuşlardır. Boztaş (2015) eğitim bilimleri alanına katkı sağlamak, polis eğitimine bakış açısı kazandırmak gerekçesi ile Balıkesir Polis Meslek Yüksekokulu'nda uygulanan örtük programın kapsamını incelemiştir. Araştırmalarda, ilköğretim kademesinde sosyal becerilerin kazanımı sürecinde örtük programın işlevinin belirlendiği (Serhatlıoğlu, 2012), sosyoekonomik düzeylere göre okullarda örtük programın 
olumlu olumsuz unsurlarının ortaya çıkarıldığı ve bu unsurların öğrenciler üzerinde oluşturduğu stres düzeyinin tespit edildiği (Yıldırım, 2013) de görülmüştür. Türkiye'deki araştırmalarda (Boztaş, 2015; Serhatlıoğlu, 2012; Yıldırım, 2013) öğretmenlerin nitelikli öğrenme ortamları oluşturmalarına katkı sağlama amacına hizmet etmek için örtük programın irdelendiği görülmüştür.

Program türleri kapsamında yer alan ihmal edilen program konusunda Tatar (2019) Türkiye'de öğretmen, öğretim elemanı ve eğitim sendikası temsilcileri tarafından tartışmalı konuların belirlenmesi ve bu konularla ilgili gerçek sorunların ortaya çıkarılmasını gerekli görmüş; ilköğretim ve ortaöğretim programlarında yer alan ve eğitim paydaşlarının görüşlerine göre tartışmalı görülen konuları incelemiştir. Mohr ve Welker (2017) ise program türleri teması kapsamında bütünleşik programın uygulanmasının önündeki engelleri belirlemek ve çözüm üretmek amacıyla 21 . yüzyıl becerilerinin gelişimi ile aralarındaki ilişkiyi incelemiştir.

\section{Program Değerlendirme}

Tablo 1'e göre, Türkiye'deki araştırmalarda üzerinde çalışılan diğer bir konu da program değerlendirmedir. Araştırmalarda program değerlendirme sorunlarının irdelendiği model (Selvi, Uysal, Polat, Sönmez, Köse ve Yetim, 2016) ve ölçüt geliştirmeye (Kürüm Yapıcıoğlu, Atik Kara ve Sever, 2016; Yazçayır, 2016; Yazçayır, Selvi ve Demirel, 2013; Yüksel, 2010) odaklanıldığı görülmüştür. Model geliştirme açısından Selvi, Uysal, Polat, Sönmez, Köse ve Yetim (2016), alanyazındaki araştırmalarda program geliştirmenin program tasarısı ile karıştırıldığını, bu kavramsal karmaşanın giderilmesi gerektiğini vurgulamış ve bu amaçla bir program geliştirme model önerisi oluşturmuşlardır. Ölçüt geliştirmeyi konu olarak ele alan Yazçayır (2016), program değerlendirme çalışmalarının tercih edilen model fark etmeksizin AR-GE işlevini gerçekleştirdiği ve programın geliştirilmesine hizmet ettiği gerekçesiyle, Demirel Analitik Yararlanıc Program Değerlendirme Modeli "DAPDEM" kapsamında "Program Değerlendirme Ölçütleri" geliştirmiştir. Yazçayır vd. (2013) ise standart oluşturmak açısından önceki ve mevcut programların değerlendirme ölçütleri temelinde programları karşılaştırmalı olarak analiz ederken; Yüksel (2010), ABD'de bulunan Ortak Komite tarafından geliştirilmiş standartlar ve

program geliştirme uzmanlarının görüşleri kapsamında program değerlendirme ölçütlerini oluşturmuştur.

\section{Toplumsal Etmenler}

Tablo 1'deki toplumsal etmenler teması kapsamında, göçü araştıran araştırmaların çıkış noktalarından biri göçle gelen öğrencilerin yaşadıkları duygusal travmalar ve kimlik oluşturma sorunlarının programa yansıyan yönlerini ortaya koyma isteğidir (Jarratt, 2020). Anwaruddin (2017), Bajaj ve Barlett (2017) ile Guo ve Maitra (2017), göçmenleri tanımayı ve onların farklı kültürel bakış açılarının programa nasıl yansıtılabileceğini araştırmayı gerekli görmüşlerdir. Nieto ve Bickmore (2017) güç dengesinin göç konusunda önemli bir unsur olduğu gerekçesiyle, toplumsal güç dengeleriyle beraber Kanada ve Meksika'da bu konunun programa nasıl yansıdığını araştırmışlardır. Salter (2014) göç konusunu Asya okuryazarlığı ile eş değer görmüş ve Avustralyalı eğitim bilimcilerin Asya kültürü ve epistemolojilerini irdelemiştir. Osmond-Johnson ve Turner (2020) ise, Kanada'daki K-12 eğitiminde eyleme geçme ve programla bütünleşme açısından, yerli okul müdürlerinin yerli olmayan, aynı kültüre sahip olmayan müdürlerle nasıl uzlaştığını ortaya çıkarmayı gerekli bulmuşlardır.

Toplumsal etmenler teması kapsamında, sosyal adaleti konu edinen araştırmalardan birinde Sonu (2016) aynı kent okulundan mezun olan kişilerin sosyal adalete yönelik deneyimlerini ortaya çıkarmak amacıyla, bu deneyimlerin sosyal adalet ve sosyal projelerin gelişimine etkisini incelemiştir. Bray, Kobakhidze, Zhang ve Liu (2018), Kamboçya'da gölge eğitimin okuldaki aynı öğretmen, aynı 
öğrencilerle süregeldiğine ve sosyal eşitsizliklerin yaşandığına dikkat çekerek programın arz ve talep dengelerini ortaya çıkarmayı amaçlamıştır. Skelton ve Francis (2011), erkeklerin kadınlara göre daha az başarılı olduğunu ve Avustralya ve Birleşik Krallığın bu durumu düzeltmesi gerektiğini araştırma problemi olarak tanımlamışlardır; erkeklerin maskülen statüleriyle başarılı okuryazarlık kimliklerini nasıl koruyacaklarını ve farklı değişkenlerin başarıya etkisini çözümlemişlerdir. Desai (2016), Amerika'da Yükselen Kızlar (Rising Girl) filmi ve kampanyası sayesinde ulusal, yerel ve küresel anlamda kızların eğitimlerinden vazgeçilemeyeceğinin anlaşıldığı gerekçesiyle, 3. Dünya Kızları adını verdiği göstergelerin oluşturulmasında ve duygularının yansıtılmasında programın etkisini ortaya çıkarmayı amaçlamışlardır.

Toplumsal etmenler teması kapsamında, demokrasi eğitimini inceleyen Hakwoort ve Olsson (2014) demokratik değerler ve yeterliklerin artırılmasına yönelik araştırmalarını, İsveç eğitim politikasının iki misyonu olarak belirlenen içerik temelli öğretim ve demokratik değerlerin, okullarda uygulanmadığı problemi üzerine yapılandırmışlardır. Çevre eğitimi konusundaki araştırmada ise; Moroye ve Ingman (2013) ekolojinin içselleştirilmesi açısından program olarak görülmesi gerektiğini vurgulayarak, ekolojik düşünmenin eğitime yansıyan yönlerini ortaya çıkarmayı amaçlamışlardır.

Toplumsal etmenler teması kapsamında çalışılan diğer bir konu ise cinsel eşitliktir. Bu konuda, Stiegler (2016), ABD'de trans öğrenci haklarının genişlemesine karşı çıkan aktivistlerin cinsiyet mahremiyet çocuk hakları hakkında örtük ve gerçek rejimlerini ortaya çıkarmayı amaçlamıştır. Kaliforniya Eyalet Meclisinde kabul edilen trans öğrenci haklarına yönelik yasanın eyalet genelinde öğrencilere yansımalarını incelemiştir. Gacoin (2016), HIV virüsünden korunmak için uygulanan cinsel eğitim programlarının gençlerin cinsel kimliklerini güçlendirmesine karşın etik açıdan eleştirmiş, konunun karmaşık pedagojik anlamlar içerdiğini vurgulamıştır. Martino ve Potvin (2011) ise, aynı cinsiyetten insanların evlenmesi bazı ülkelerde normal kabul edilirken Avustralya'da normal kabul edilmediği gerekçesiyle aynı cinsiyetten evlenmiş ebeveynlere yönelik, iki ilkokul öğretmeninin pedagojik yaklaşımlarını incelemeyi değerli bulmuştur.

Toplumsal etmenler teması kapsamında ırksal eşitliği inceleyen araştırmaların varlığı dikkati çekmektedir. Örneğin, Hong ve Halvorsen (2010), Amerika'daki eğitim programlarında Asya'nın ötekileştirilerek anlatıldığı gerekçesiyle, Asya ile ilgili bilgilerin öğretiminin programı nasıl etkilediğini ortaya çıkarmayı amaçlamışlardır. Limes ve Henderson (2019), Birleşik Krallıktaki siyahileri sömürgeleştirme, asimile etme çabalarının nedenlerini irdelemek için Afrikalı siyahilere yönelik eğitim hareketlerini incelemiştir. Thomas (2019) ise, öğrencisi ile siyahi olma diyaloğu üzerine örtük programdaki beyaz üstünlüğünün etkilerini dönüştürebileceğini araştırma problemi olarak algılamıştır. Bryan (2012) eğitim programlarında karşılaşılan dominant ırkçı söylemi öğrenci görüşleri üzerinden irdelemiştir.

\section{Yeniden Kavramsallaştırma}

Yeniden kavramsallaştırma teması kapsamında, yurtdışında eleştirel pedagojiyi konu edinen araştırmalara rastlanmıştır. Örneğin De Leon (2019) Kolombiya'da savunmasız nüfusa (azınlık gruplar, özel gereksinimli insanlar, sistem dışı kalan çocuklar) hizmet etmek amacıyla eleştirel söylem analizini kullanarak eğitim politikasının bir parçası kabul edilen Öğrenmenin Hızlandırılması (Aceleración del Aprendizaje) programını incelemiştir. Pennell (2016) ortaokul matematik ve sosyal adalet dersinin programını sosyal adalet pedagojisi, cinsiyet kuramı, eleştirel okuryazarlık ve eleştirel matematik konularını bütünleştirerek oluşturmuş ve sonuçlarını değerlendirmiştir. Rombalski (2020) Minneapolis'te yer alan iki okulun kültürünü eleştirel pedagoji bağlamında irdelemiş, genç aktivist pedagoji uygulamalarını yorumlamıştır. Yeniden kavramsallaştırma teması kapsamında çalışılan diğer bir konu sibernetiktir. Ivens (2018) sibernetiğin 20. yüzyılın ortalarında Amerikan eğitim ve sosyal 
reformlarındaki rolünü, eğitim programı ve program tasarımcıları için alanda model olan Tyler Mantığı (Rationale) ile ilişkilendirerek incelemiştir.

Yeniden kavramsallaştırmacılık kapsamında programların politik metin olarak değerlendirilmesini konu edinen Korkmaz (2016), Türkiye'deki eğitim programlarına farklı bir bakış açısı kazandırmak gerekçesiyle politikanın programlara etkisinin ortaya çıkarılması gerektiğini belirtmiştir. Şiraz (2020) ise, araştırmasına, eğitim programlarını politik metin bağlamında anlamaya yönelik çalışmaların alana katkı sağlayacağını gerekçe göstermiştir. Korkmaz (2016), 6. sınıf sosyal bilgiler öğretim programını, Şiraz (2020) ise sosyal bilgiler öğretim programında yer alan vatandaşlık eğitimini yeniden kavramsallaştırma akımı bağlamında politik metin olarak incelemiştir. Erginer ve Örten (2016) program geliştirme alanına ne tür anlamların yüklendiğinin tespit edilmesi ve alanın gelişimine katkı sağlamak gerekçesiyle öncü akademisyenlerin alanla ilgili kullandıkları metaforları ortaya çıkarmıştır.

\section{Tartışma, Sonuç ve Öneriler}

Bu çalışmada incelenen program araştırmalarında, politik etmenlerin önemli ölçüde problem olarak tanımlandığı saptanmıştır. Yurt dışında, ülkenin yönetim biçiminin program çalışmalarını etkilediği düşüncesiyle, ideolojik bakış açılarının programlara etkilerini inceleyen araştırmalar bulunmaktadır (Mansur ve Malik, 2016; Mølstad, 2015; Yang ve Li, 2018; Zhao, 2020). Bu düşünceyi destekleyen Özsoy'a (2012) göre ülkeler mevcut sistemlerine uygun insan tipi yetiştirmeyi hedeflemekte bu nedenle programlara yön veren yönetimlerin değişmesiyle programlar da güncellenmektedir. Apple (2004) ise siyasi hegemonyanın varlığını sürdürme aracı olarak, programı kullandığını vurgulamıştır. "Kimin bilgisi önemlidir?" sorusu ile eğitimin; ideolojinin ve politikanın merkezinde olduğunu programdaki konuların iktidar tarafından kasıtlı ve belli amaçlar doğrultusunda seçildiğini iddia etmektedir. Bu çalışmada incelenen araştırmalarda programı anlama ve anlamlandırma çabalarının, yönetim biçimini çözümleme temeline dayandığı anlaşılmaktadır. Sonuç olarak yönetim biçiminin programlara etkilerinin irdelenmesi programların arka planındaki görüşleri ve amaçları ortaya çıkarması açısından önemli bir araştırma konusudur.

Incelenen araştırmaların bazılarında politik gündemlerin programları ve okul ortamlarını etkilediği öne sürülmüştür (Akrom, 2015; Garrett, 2020; Ito vd., 2015; Jang, 2017; Wu, 2012). Oysaki bugün ve geleceğe yönelik çözümler üretmek kaostan uzak, isabetli eğitim politikaları ve uygulamaları ile mümkündür. Özetle, programların ve eğitim ortamlarının, o anki politik gündemin etkisi altında olması nedeniyle ülkelerin politik gündemlerinin irdelenmesi, program araştırmalarında önemli bir yer tutmaktadır.

Politik etmenlerin hesap verebilirlik bağlamında ele alındığı bir araştırmada Mathou (2018), hesap verebilirliğin mesleki kimliği şekillendirdiği düşüncesini temele almıştır. Hesap verebilirlik kavramının politik olarak oluşturduğu baskı, öğretmenleri kendini geliştirmeye, daha iyi eğitim anlayışı oluşturmaya yöneltmektedir. Bu nedenle, program araştırmalarında hesap verebilirliğin mesleki gelişime etkisinin yer aldığı görülmektedir. Bununla birlikte, hesap verebilirliğin programları etkilediği ve dönüştürdüğü düşünülmektedir. Dolayısıyla, program araştırmalarında hesap verebilirliğin program paydaşlarına etkileri açısından incelenmesi ve tartışılması eğitimin nasıl olması gerektiğine ilişkin düşünceleri ortaya çıkarmada etkili olabilir.

Başarıyı değerlendirme politikalarına yönelik araştırmalar (Dutro ve Selland, 2012; Yoon, 2016) öğrenci için hayati önem taşıyan testlerin öğrenciye yansımalarını konu edinmiştir. Testlerin sağlıksız öğrenme ortamı oluşturduğu görüşü (Hamilton, Berends ve Stecher, 2005), bu çalışmaların gerekçelerini desteklemektedir. Kim ve Jong (2019), Güney Kore'de öğrenci başarısını değerlendiren 
testlerde yüksek başarı elde etmek isteyen öğrencilerin eğitimlerini okul dışında gölge programlar (shadow curriculum) uygulayan etüt merkezlerinde sürdürdüklerini belirtmiştir. Başarıyı değerlendirme politikaları nedeniyle gölge programın dünya genelindeki alanyazında güncel bir eğitim kavramı olduğu vurgulanmıştır (Ventura ve Jang, 2010). Buna bağlı olarak standart ve norm dayanaklı testlerin programlar üzerindeki etkilerinin araştırıması, program çalışmalarına katkı sağlayabilir.

Uluslararasılaşma ve küreselleşme konularındaki araştırmalarda (Donald-Whitney, 2019; Pantić ve Wubbles, 2012; Whitaker, 2012) uluslararası yeterlik konularının da program çalışmalarını yönlendirdiği görülmektedir. Sürekli dönüşüm ve gelişim içinde olan dünyada eğitim programlarının, bu değişimlerden etkilenmemesi düşünülemez (Gömleksiz ve Kılınç, 2012). Bu nedenle küresel vatandaşlık, çok kültürlü eğitim, yaşam boyu öğrenme, fırsat eşitliği gibi küreselleşme sonucu ortaya çıkan kavramlar bu değişime ayak uydurmaya çalışan gelişmiş ülkelerin eğitim reformlarında ön plandadır. Kovid-19 nedeniyle dünya ülkelerinin sınırlarını kapatması sonucunda eğitim, sağlık gibi alanlarda ayrışmalarla birlikte siyasi ve ekonomik krizlerin yaşandığı, küreselleşmenin bu salgın ile sarsıldığı belirtilmektedir (Kozlov ve Sokolova, 2020). Program çalışmalarında, olağanüstü durumlara uyum sağlayabilme, uluslararası standartları yakalama, gelişimi ve değişimi takip etme çabalarının yanı sıra salgının olumlu ve olumsuz etkileri üzerine yapılacak araştırmaların alana yön verebileceği düşünülmektedir.

Merkezi program yaklaşımı temasında yurtdışında bir araştırmaya ulaşıımıştır. Yang ve Li (2018) güney Çin'deki okul temelli eğitim programlarının doğası ve mekanizmalarını sosyokültürel ve tarihsel açıdan karşılaştırmalarla irdelemiştir. Türkiye'deki araştırmalarda, politik etmenlerin çoğunlukla merkezi program yaklaşımı (Bay vd., 2016; Demiralp, 2017; Filiz ve Baysal, 2019; Mızıkacı vd., 2019; Özyurt vd., 2016) kapsamında ele alındığı görülmüştür. Ekonomik Kalkınma ve İşbirliği Örgütü'nün bir raporuna göre, Türkiye merkeziyetçi yapıdadır ve öğretmenlerin okul yönetimine katılımı açısından 36 ülke arasında son sıradadır (Organisation for Economic Co-operation and Development [OECD], 2017). Şahin ve Kumral (2013), merkezi program anlayışı nedeniyle, öğretmenlerin programları "müzisyenlerin takip ettiği notalar" olarak yorumladıklarını vurgulamıştır. Bu nedenle, program araştırmalarında Türkiye'deki merkeziyetçi çalışmaların sonuçlarının belirlenmesine, farklı modellerin denenmesine, yönetsel süreçlerin ve uygulamaların iyileştirilmesine katkı getirebilir.

Bu çalışmada, uzak hedeflerin programlara yansımalarını inceleyen bir araştırmaya (Özkan, 2018) ulaşılmıştır. Uzak hedefler ülkenin önem verilen kavramlarını, değer yargılarını, eğitimin amacını yansıtmaktadır (Oliva, 1982; Ornstein ve Hunkins, 2018). Sönmez (2019) Türkiye'deki parti yönetimlerinin eğitim dizgesini kendi amacı için araç olarak görmesini ve uzak hedeflerin sürekli değiştirilmesini eleştirmiştir. Bu nedenle farklı bağlamlardaki politik anlayışların uzak hedeflere yansımalarının araştırıması değerlidir.

Program - paydaş etkileşimi kapsamında, programa bağıııı konusunda, Türkiye'deki araştırmalar (Bümen ve Yazıcılar, 2019; Tokgöz, 2013) programların hedeflerine ulaşması açısından öğretmenlerin program uygulamalarına ve programa bağlıı̆̆ı etkileyen etmenlere odaklanmaktadır. Fullan ve Pomfret'e (1977) göre, programların nasıl uygulandığı bilinmeden etkisi üzerine değerlendirme yapılamayacağı için programa bağlılık konusundaki araştırmalara ihtiyaç vardır. Yurtdışındaki araştırmalarda ise programa bağlılı̆ın meslek etiği (Sholtz, 2020), mesleki yeterlilik (Toledo, 2020), öğretmen özerkliği (Erss vd., 2016; Mcinerney, 2019) ve programın etkililiği (Burti, 2010; Cullen ve Jordan, 2011; Fahey, 2012) açısından ele alındığı görülmüştür. Öğretmenlerin programları farklı sosyoekonomik düzeylerden ve ırklardan olan öğrencilerin ihtiyaçlarını dikkate alarak düzenleyebilmelerinin günümüzde göç almakta olan ülkelerin ortak hedeflerinden biri olabileceği öngörüsüyle, programa bağlılık konusunun araştırılması gerektiği düşünülmektedir. 
Program - paydaş etkileşimi kapsamında program okuryazarlığı konusundaki araştırmalarda (Bolat, 2017; Kahramanoğlu, 2019; Özer ve Alkan, 2017), çoğunlukla, öğretmenlerin program okuryazarlığı becerileri üzerinde çalışılmıştır. Programların doğru ve olması gerektiği düzeyde hayata geçirilmesi, öğretmenlerin programların kapsamını, yapısını ve özelliklerini anlamasına bağlıdır (Akınoğlu ve Doğan, 2012). Türkiye'de de merkezi programların uygulamaya dönüştürülmesi program okuryazarlığı ile ilişkilidir. Dolayısıyla MEB tarafından hazırlanan programların benzer biçimde uygulanmasını sağlamak için öğretmenlerin program okuryazarlıklarının tespit edilmesi ve geliştirilmesi, programı algılama biçimlerinin araştırılması önemli görülmektedir.

Program değişikliğine uyum sürecini inceleyen yurtdışındaki araştırmalarda (Jarvis, 2012; Thompson, 2019) yükseköğretim ve Bakalorya programının amaçlarının gerçekleştirilmesine önem verilmiştir. Programa uyum sürecinin sağlanması açısından Rogers'a (2003) göre öğretmenlerin programdaki yenilikleri algılaması için yenilikleri fark etme, ikna olma ve karar verme basamaklarına zaman içinde ulaşması gereklidir. Bu nedenle paydaşların program değişikliğine uyum sürecini kolaylaştırmayı amaçlayan araştırmalara ihtiyaç vardır.

Incelenen araştırmalarda program türlerinden örtük, ihmal edilen ve bütünleşik programlar yer almaktadır. Türkiye'de, örtük programın öğrencilere farklı yönlerden etkilerini gösteren araştırmaların (Akbulut ve Aslan, 2016; Boztaş, 2015; Çengel ve Türkoğlu, 2016; Serhatlığlu, 2012; Tuncel ve Demirel, 2018) programların işlevlerinin belirlenmesine odaklandığı görülmüştür. Bireyin, toplumun işlevsel bir üyesi olması için, Posner'a (2004) göre örtük programlar çoğu zaman resmi programlardan daha etkili olabilmektedir. Mariani (1999) ise resmi programları buzdağının görünen yüzüne benzetmiş; öğrenci öğretmen, aile ve yöneticilerin inanç, güdülenme, tutum ve beklentileri doğrultusunda programa ne kattıklarını gösteren örtük programın önemini vurgulamışır. Son dönemde, küresel salgın nedeniyle uzaktan öğretimin etkisiyle örtük programların da değişime uğrayabileceği düşünülmektedir. Yakın gelecekteki program araştırmalarında uzaktan öğretimle birlikte örtük programın yapısı ve işlerliği gibi konuların ele alınabileceği öngörülmektedir.

Program türleri kapsamında ihmal edilen programın incelendiği araştırmada (Tatar, 2019) Türkiye bağlamında tartışmalı konular irdelenmiştir. İhmal edilen programa ilişkin McLaren (2011) bazı bilgilerin baskın kültürü oluştururken bazı bilgilerin neden geri plana itildiğini sorgulamıştır. Tatar'a (2019) göre eğitsel değeri yanlış anlaşılan konuların inmal edilmesi, bireylerin bu konuların kendilerine sunacağı imkânlardan yoksun bırakılmasına neden olmaktadır. İhmal edilen programlarda kasıtlı olarak program dışı bırakılan konuların tespit edilmesinin toplumun gerçekliğine dair bakış açısı sunabileceği düşünülmektedir.

Bütünleşik program ile ilgili yurtdışındaki araştırmada (Mohr ve Welker, 2017), bütünleşik program ile 21. yüzyıl becerileri olarak ifade edilen iletişim, iş birliği yapma, eleştirel düşünme, dijital okuryazarlık, öz denetim, sosyokültürel beceriler ve yaratıcılık açısından incelenmiştir. Bütünleşik programın ortak bir tanımı olmasa da birden fazla konu alanındaki becerilerin, amaçlı bir şekilde birlikte hazırlanarak bağlanması olarak ifade edilebilir (Krogh ve Morehous, 2014). Hızla değişime uğrayan dünyada okullardan öğrencilere 21. yüzyıl becerileri olarak anılan eleştirel düşünme, iletişim, iş birliği gibi becerileri kazandırması beklenmektedir (National Research Council, 2012). Bu nedenle bütünleşik programa ilişkin araştırmaların artmasında yarar görülmektedir.

Program değerlendirmeye ilişkin araştırmalar model geliştirme ve standart oluşturma başlıkları altında incelenmiştir. Yurtiçindeki araştırmaların (Selvi vd., 2016; Yazçayır, 2016; Yazçayır vd., 2013; Yüksel, 2010) temelinde program çalışmalarını daha iyi noktaya getirme düşüncesi olduğu görülmüştür. Programların toplumun sürekli değişen ihtiyaçları, bilim ve teknolojideki gelişmeler ışığında sürekli 
olarak gözden geçirilmesi gerekmektedir. Bu nedenle, program değerlendirme model önerilerinin sistematik biçimde programların değişimi ve gelişimini destekleyerek alana katkı sağlayacağı düşünülmüştür. Diğer yandan, Fitzpatrick, Sanders ve Worthen'a (2004) göre programlar hakkında bir yargıya varmak, değerlendirebilmek amacıyla ölçüt ve standartlar oluşturulmalıdır. Dolayısıyla program araştırmalarında değerlendirme ölçütlerinin oluşturulması ve geliştirilmesi, program değerlendirme çalışmalarını destekleyebilir.

Toplumsal etmenler temasında göçün etkisi, sosyal adalet, demokrasi eğitimi, çevre eğitimi konularındaki araştırmalar (Anwaruddin, 2017; Bajaj ve Barlett, 2017; Guo ve Maitra, 2017; Nieto ve Bickmore, 2017; Osmond-Johson ve Turner, 2020; Salter, 2014) yer almıştır. Gözütok'a (2005) göre eğitim programları toplumun gerçekliğidir. Bu nedenle programların değişim sürecinin irdelenmesi; verimli programların geliştirilmesi ve alana katkı sağlaması açısından önemli görülmektedir. Bu çalışmada ülkelerin izlediği göç politikalarının eğitim programlarının içeriğine farklı kültürel kimliklerin yansıdığı ve araştırmaları etkilediği görülmüştür. Alanyazında heterojen kimliğe sahip ABD'de "Melting Pot" gibi etnik asimilasyon teorilerinin yerini çeşitliliğin zenginlik olarak görüldüğü "Salad Bowl" teorisine bıraktığı belirtilmiştir (Cho, 1995, Akt. Mahfouz, 2013). Apple'a (2004) göre ise durum göründüğü gibi değildir; egemen güçlerin kültürel farklılıkla ilgilendiği düşünülür ancak resmi programlarda dilsel, ırksal, kültürel ayrımcılıklar söz konusudur. Oysaki farklııkları benimseyen değer verici bir kavram olan çok kültürlülük toplumun bütünleşmesini sağlayabilir (Banks, 2013). Alanyazında göçle gelen öğrenci ihtiyaçlarını karşılayacak, çok kültürlülük anlayışının benimsendiği okul iklimleri oluşturulmasının önemli olduğu ancak öğretmenlerin çok kültürlülüğe ilişkin yeterli bilgilerinin olmadığı vurgulanmıştır (Banks, 2013). Bu tür tespitler, öğretmen eğitimi programlarında çok kültürlülük çalışmalarının araştırılmasına intiyaç olduğunu göstermektedir. Ayrıca, eğitim programlarının kültürel etkileşimin hız kazandığı yerelden evrenselliğe geçişin arttığı toplumlarda göçün etkileri ve çok kültürlülük bağlamında incelenmesi alana yeni değer ve yaklaşımlar sağlayabilir.

Sosyal adaleti inceleyen yurtdışındaki araştırmalarda cinsiyet eşitsizliği ve sosyal eşitsizliğin programları etkilediği saptanmıştır (Bray vd., 2018; Desai, 2016; Martino ve Potvin, 2011; Skelton ve Francis, 2011). Eğitimde bütün politikalar eşitlik, adalet gibi değerler üzerinden oluşturulmalıdır (Şişman, 2006). Bununla birlikte sosyal adaletin kimler için hangi dezavantajlı bireyler için sağlanması gerektiği ise ülkeden ülkeye değişiklik göstermektedir. Programlar toplumu yansıtan aynalar olmakla birlikte, toplumun sahip olduğu kültürü ve hükümetlerin eşitsizlik adına yürüteceği eğitim politikalarını da etkilemektedir (Tomul, 2009). Dolayısıyla sosyal adalet konusundaki program araştırmaları toplumu oluşturan tüm bireylere eşit eğitim fırsatı sunma ve demokratik öğrenme ortamları oluşturmada etkili olabilir.

Demokrasi eğitimini inceleyen Hakwoort ve Olsson (2014), demokratik değerler ve yeterliliklerin programa yansımalarını konu edinmiştir. Demokratik toplumu oluşturmanın ön koşulu demokratik eğitimdir. Eğitimin demokratik yaşamın değerlerini yansıtması için demokratik değerleri barındıran içeriğin programlara eklenmesi demokratik kültürün oluşmasında yeterli değildir. Gutek'e (2001) göre, "okul demokratik toplumun minyatürü olmalı" (s. 217) ve bireylerin demokrasiyi içselleştirmelerini sağlamalıdır. Dolayısıyla, demokratik rejimleri sürdürme çabalarının program araştırmalarında önemli bir yeri olduğu; demokrasi eğitiminin değerleri ve uygulama boyutlarıyla araştırılması gerektiği düşünülmektedir.

Çevre eğitimini araştıran Moroye ve İngman (2013), insanlığın geleceği için ekolojik bilincin oluşturulmasının önemine odaklanmıştır. Çevre eğitimi, etik eylemlerle ilişkili olmakla beraber bir yaşam biçimidir (Davis, 1998). Küresel ısınma, açlık, iklim değişikliği, bazı canlı türlerinin yok olması, ekolojik dengenin bozulması gibi birçok sorunla karşı karşıya olan dünya için ekolojik bilincin program araştırmalarıyla irdelenmesi ve geliştirilmesine ihtiyaç vardır. 
Toplumsal etmenler kapsamındaki araştırmalarda ırkçı ve cinsel eşitliğe yönelik bakış açılarının programları etkilediği görülmüştür (Bryan, 2012; Hong ve Halvorsen, 2010; Rombalski, 2020). Yurt dışında cinsel kimlik temelli ayrımcılığın ele alındığı araştırmalarda farklı pedagojik yaklaşımların bireylerin haklarını koruyabileceği ve programların etkili uygulanabileceği düşünceleri temele alınmıştır (Gacoin, 2016; Martino ve Potvin, 2011; Stiegler, 2016). Eğitimde heteroseksüellik normalitesinin ötesine geçen normallik içinde özümsenmek yerine çoğulculuğun beslendiği sosyal değişimi başlatan, güç dinamiklerini değiştiren ve sorgulayan queer pedagoji yaklaşımları kullanılmalıdır (Pinar, 1988, Akt. Martino, 2006). Britzman'a (1995) göre "Queer Pedagoji” yaklaşımlarının kullanılması öğretmenin kalıplaşmış yargılarından sıyrılması ile mümkündür. Fakat Valenti ve Campbell (2009) toplumsal normları benimseyen öğretmenlerin queer öğrencilerinin haklarına saygı göstermediği gibi ayrımcılı̆ı teşvik eden söylemlerde bulunduğunu tespit etmiştir. Sonuç olarak eğitim ortamlarının ve program uygulamalarının queer pedagoji kapsamında incelenmesi, cinsel eşitliğin sağlanmasına katkı sunabilir.

Irksal eşitliğin konu olarak ele alındığı araştırmalarda (Hong ve Halvorsen, 2010; Limes ve Henderson, 2019; Thomas, 2019), programlarda ötekileştirme unsurları olduğu belirlenmiştir. Geçmişten günümüze okullarda ve üniversitelerde siyahiler ve farklı etnik kimliğe sahip öğrenciler baskın öğretim biçimlerine maruz kalmışlardır ve bu durum büyük olasılıkla devam edecektir (Woodson, 2015). Rombalski (2020) Amerika'da sosyal eylemler (Black Life is Matter) ile ırkçılığa karşı oluşan farkındalığın eğitim programlarına yansıtılabileceğini belirtmiştir. Dolayısıyla program araştırmalarında ırkçılığın irdelenmesi, ırkçı olmayan bir eğitimin nasıl olması gerektiğine ilişkin fikirleri ortaya çıkarması açısından önemli görülmektedir.

Yeniden kavramsallaştırma bağlamında incelenen araştırmaların eleştirel pedagoji (De Leon, 2019; Pennell, 2016), sibernetik (Ivens, 2018) ve politik metin olarak inceleme (Erginer ve Örten, 2016; Korkmaz, 2016; Şiraz, 2020) konularına odaklandığı görülmüştür. 1970'li yıllarda tarihi ve siyasi olayların da etkisiyle ortaya çıkan yeniden kavramsallaştırmacılık, eğitim programlarındaki geleneksel anlayışa karşı çıkmaktadır. Yeniden kavramsallaştırmanın eleştirel pedagoji bağlamında incelendiği araştırmalarda, Pennell (2016) eğitimin toplumu değiştirmek ve dönüştürmek için bir araç olduğu düşüncesini ele almış, Rombalksi (2020) ise gençlerin okul kültürü üzerindeki etkisine odaklanmıştır. Eleştirel pedagoji çatısı altında yer alan ve programı politik bir metin olarak inceleyen Apple'a (2010) göre de toplumu şekillendiren programın kalbinde siyasi hegemonya bulunmaktadır. Politik bilgi, programın tüm kelimeleri arasına sinmiştir (Korkmaz, 2016). Giroux (1997) ise okulları ideolojilerin denetim kaynağı olarak belirtmiştir. Giroux (1997) ve Freire (2008) toplumsal yapıya uygun yetiştirilen bireylerin kurumlara bağımlı kaldığını ve okulların benzer kimliklere sahip bireyleri yeniden üretmesi ile eğitimde fabrika benzeri yapının oluştuğuna dikkat çekmişlerdir. Yeniden kavramsallaştırmayı eleştiren Wraga (1999) ise okullardan uzaklaşmayı kuram ve uygulamanın birbirinden kopması olarak yorumlamıştır. Bu çalışmada, Türkiye'de programın politik metin olarak incelendiği araştırmaların (Erginer ve Örten, 2016; Korkmaz, 2016; Şiraz, 2020) sınırlı olduğu görülmüştür. Korkmaz (2016) ve Şiraz (2020) araştırmalarında eğitim programının fenomenolojik, tarihsel, cinsiyet temelli gibi farklı anlama tarzları ile incelenmesinin önemini belirtmiştir. Erginer ve Örten (2016) ise program alanının anlamını metaforlar üzerinden irdelemiştir. Programın politik, kültürel, siyasal ve toplumsal açılardan çözümlenmesi ile alandaki yeniliklerin ve güncel konuların irdelenmesinin ülkemizde EPÖ alanının gelişimine de katkı sağlayabileceği düşünülmektedir (Bümen ve Aktan, 2014). Dolayısıyla programların ırksal, toplumsal cinsiyet, fenomenolojik, post yapısalcı ve post modern söylemleri temele alarak incelenmesinin alana katkı sağlayacağı düşünülmüştür.

Yeniden kavramsallaştırma kapsamında sibernetik konulu yurtdışındaki bir araştırma Ivens (2018) tarafından gerçekleştirilmiştir. Öz düzenleme bilimi olarak tanımlanan bu kavramın program araştırmalarında yer edinebileceği düşünülmektedir. Öz düzenleme ilkeleri, öğrenmeyi öğrenme gibi 
çalışma konuları sibernetiğin içinde yer almakla birlikte geribildirim gibi terimlerin de eğitim bilimlerinde kullanıldığı görülmektedir (Pratt, 1982). Bu nedenle sınırlı sayıda araştırmanın olduğu tespit edilen sibernetiğin salgın sürecinde, uzaktan eğitim ile öz düzenleme ve öğrenmeyi öğrenme becerilerinin sorgulandığı mevcut durumda program araştırmalarına farklı bir boyut getireceği öngörülmektedir.

Özetle, bu çalışmada yurtdışındaki araştırmaların yönetim biçiminin etkisi, politik gündemin etkisi, hesap verebilirlik, başarıyı değerlendirme politikaları, uluslararasılaşma / küreselleşme, programa bağ|ılık, örtük program, bütünleşik program, göçün etkisi, sosyal adalet, demokrasi eğitimi, çevre eğitimi, ırksal ve cinsel eşitlik, eleştirel pedagoji, sibernetik konularında yoğunlaştığı; Türkiye'de uluslararasılaşma / küreselleşme, merkezi yaklaşım, uzak hedefler, laiklik, programa bağlılık, program okuryazarlığı, program değişikliğine uyum süreci, örtük program, ihmal edilen program, program değerlendirme modeli geliştirme, program değerlendirmede ölçüt geliştirme, program teorisi konularına ağırlık verildiği sonucuna ulaşılmıştır. Ayrıca, program araştırmalarının yenilikçi, alandaki problemlere çözüm üreten, alanın iyileştirilmesine katkı sunabilecek düzeyde olması beklenmektedir. Bu sonuçlar doğrultusunda aşağıdaki öneriler geliştirilmiştir:

- Bu çalışma yurtiçinde 26 ve yurtdışında 39 olmak üzere Journal of Curriculum Studies ve Curriculum Inquiry dergilerinde yayınlanan 65 makale; yurtiçinde 13 ve yurtdışında 13 olmak üzere toplam 26 doktora tezinin incelenmesi ile sınırlıdır. Araştırmada son 10 yıl içinde yayımlanan makale ve tezler incelenmiş olup ileride daha kapsamlı çalışmaların yapılması alanyazına daha fazla katkı sağlayabilir.

- Program araştırmaları cinsel eşitlik, ırksal eşitlik, sosyal adalet, dijital yeterlilikler, çok kültürlü eğitim, küresel salgının etkisiyle okul sistemlerinde değişen dinamikler, öğretmenlerin salgın ile birlikte mesleki açıdan değişime uğrayan mesleki yeterlilik alanları, okullardaki personelin çeşitlenmesi, öz düzenleme gibi konular üzerine yoğunlaşabilir.

- Küresel salgının etkisiyle eğitime erişim sağlayamayan öğrenciler için fırsat eşitliği oluşturmaya yönelik program araştırmaları yapılabilir.

- Salgın sürecinde dijital teknolojilerin güç kazanması ile küresel şirketlerle iş birliği içerisinde olan birçok ülke dijital platformlar vasıtasıyla eğitime devam etmiştir. Gölge programların irdelenmesi ve eğitimde yaşanan krizin tanımlanması açısından şirketlerin programlara etkileri araştırılabilir.

- Uzaktan eğitimi sürdüren öğrencilerin toplumsal travmadan ne yönde ve nasıl etkilendiği yaşadıkları olumsuz psikolojik deneyimler, siber zorbalık tehditleri, ekran karşısında geçirilen süre nedeniyle sahip oldukları fiziksel sorunlar, ev ortamında öğrencilerin karşılaştığı durumlar, ebeveynlerin dijital yeterlilikleri ve kaygı düzeyleri üzerine program araştırmaları gerçekleştirilebilir.

- Son olarak güncel çevre sorunlarından açıı, su kaynaklarının azalması, ani iklim değişimlerinin tüm dünya ülkelerinde göz ardı edilemeyecek boyutlara gelmesi nedeniyle sürdürülebilir çevre eğitimi ve ekolojik denge konulu araştırmalar hız kazanabilir. 


\section{Kaynakça}

Akdemir, E., Karameşe, E. N. ve Arslan, A. (2015). Descriptive analysis of researches on curriculum development in education. Procedia-Social and Behavioral Sciences, 174, 3199-3203. doi: 10.1016/j.sbspro.2015.01.1062

Akınoğlu, O. ve Doğan, S. (2012, Eylül). Eğitimde program geliştirme alanına yeni bir kavram önerisi: Program okuryazarlığı. 21. Ulusal Eğitim Bilimleri Kongresinde sunulan bildiri, (s. 12-14), İstanbul. Erişim adresi (17. 02. 2020): https://www.academia.edu/4423934/E\%C4\%9E\%C4\%B0T\%C4\%B0MDE PROGRAM GEL\%C4\%B0\%C5\%9 ET\%C4\%BORME_ALANINA_YEN\%C4\%B0_B\%C4\%BOR_KAVRAM_\%C3\%96NER\%C4\%B0S\%C4\%B0_PROGR AM_OKURYAZARLI\%C4\%9EI_CURRICULUM_LITERACY

Aktan, S. (2014). Curriculum research in Turkey: From the Ottoman Empire to the Republic. W. F. Pinar (Ed.), International handbook of curriculum research içinde (s. 502-510). New York: Routledge.

Apple, M. W. (2004). Creating difference: Neo-liberalism, neo-conservatism and the politics of educational reform. Educational Policy, 18(1), 12-44. doi: 10.1177/0895904803260022

Apple, M. W. (2010). Curriculum studies, the future of: Essay 1. C. Kridel (Ed.), Encyclopedia of curriculum studies içinde (s. 237-238). Thousand Oaks, CA: Sage.

Banks, J. A. (2013). Çokkültürlü eğitime giriş. (H. Aydın, Çev.). Ankara: Anı Yayıncılık.

Britzman, D. (1995). Is there a queer pedagogy? Or, stop reading straight. Educational Theory, 45(2), 151-165.

Bümen, N. ve Aktan, S. (2014). Yeniden kavramsallaştırma akımı ısığında Türkiye'de eğitim programları ve öğretim alanı üzerine özeleştirel bir çözümleme. Kastamonu Eğitim Dergisi, 22(3), 1123-1144.

Bümen, N. T. ve Yazıcılar, Ü. (2020). Öğretmenlerin öğretim programı uyarlamaları üzerine bir durum çalışması: Devlet ve özel lise farklılıkları. Gazi University Journal of Gazi Educational Faculty (GUJGEF), 4O(1), 183224.

Cohen, L., Manion, L. ve Morrison, K. (2007). Research methods in education. London: Routledge Falmer.

Demirhan İşcan, C. ve Hazır Bıkmaz, F. (2012). Eğitim programları ve öğretim alanında lisansüstü eğitim programlarının analizi ve öneriler. Eğitim Bilimleri Fakültesi Dergisi, 45(1), 107-138.

Fitzpatrick, J. L., Sanders, J. R. ve Worthen, B. R. (2004). Program evaluation-alternative approaches and practical guidelines. Boston: Pearson.

Freire, P. (2008). Ezilenlerin Pedagojisi. (D. Hattatoğlu ve E. Özbek, Çev.). İstanbul: Ayrıntı Yayınları.

Fullan, M. ve Pomfret, A. (1977). Research on curriculum and instruction implementation. Review of Educational Research, 47(2), 335-397. doi: 10.3102/00346543047002335

Giroux, H. (1997). Rewriting the discourse of racial identity: Towards a pedagogy and politics of whiteness. Harvard Educational Review, 67(2), 285-321.

Gömleksiz, M. N. ve Bozpolat, E. (2013). Eğitim programları ve öğretim alanındaki lisansüstü tezlerin değerlendirilmesi. The Journal of Academic Social Science Studies, 6(7), 457-472. doi: 10.9761/JASSS1769

Gömleksiz, M. N. ve Kılınç, H. (2012). Küreselleşmenin eğitim programları üzerindeki etkisine ilişkin akademisyen görüşleri: Nitel bir çalışma. Mustafa Kemal Üniversitesi Sosyal Bilimler Enstitüsü Dergisi, 9(17), 397-413.

Gözütok, D. (2001). Program değerlendirme. M. Gültekin (Ed.), Öğretimde planlama ve değerlendirme içinde (s. 175-190). Eskişehir: Anadolu Üniversitesi Yayınları.

Gutek, G. L. (2001). Eğitimin felsefi ve ideolojik temelleri. (N. Kale, Çev.). Ankara: Ütopya Yayınevi.

Hamilton, L. S., Berends, M. ve Stecher, B. M. (2005). Teachers' responses to standards-based accountability. Santa Monica, CA: RAND.

Hazır Bıkmaz, F., Aksoy, E., Tatar, Ö. ve Altınyüzük, C. A. (2013). Eğitim programları ve öğretim alanında yapılan doktora tezlerine ait içerik çözümlemesi (1974-2009). Eğitim ve Bilim Dergisi, 38(168), 288-303.

Huebner, D. (1976). The moribund curriculum field: Its wake and our work. Curriculum Inquiry, 6(2), 153-167. doi: 10.1080/03626784.1976.11075526

Kozikoğlu, ì. ve Senemoğlu N. (2015). Eğitim programları ve öğretim alanında yapılan doktora tezlerinin içerik analizi (2009-2014). Eğitim ve Bilim, 40(182), 29-41.

Kozlov, N. ve Sokolova, N. (2020). Deglobalization: The impact of the external environment on Russian economic development. Norwegian Journal of Development of the International Science, 38, 20-22. 
Kurt, A. ve Erdoğan, M. (2015). Program değerlendirme araştırmalarının içerik analizi ve eğilimleri: 2004-2013 yılları arası. Eğitim ve Bilim, 40(178), 199-224.

Krogh, S. L. ve Morehouse, P. (2014). The early childhood curriculum inquiry learning through integration. New York: Routledge.

Le Compte, M. D. ve Goetz, J. P. (1982). Problems of reliability and validity in ethnographic research. Review of Educational Research, 52, 31-60. doi: 10.3102/00346543052001031

Mahfouz, S. M. (2013). America's melting pot or the salad bowl: The stage immigrant's dilemma. Journal of Foreign Languages, Cultures \& Civilizations, 1(2), 1-17.

Martino, W. (2006). Straight-acting masculinities: Normalization and gender hierarchies in gay men's lives. C. Kendall ve W. Martino (Ed.), Gendered outcasts and sexual outlaws (s. 35-60) içinde. New York: Routledge.

Mariani, L. (1999, Mart). Probing the hidden curriculum: Teachers' students' beliefs and attitudes. British Council 18th National Conference for Teachers of English'de sunulan bildiri, (s.18-22), Palermo. Erişim adresi (17.02.202): http://www.learningpaths.org/papers/paperbeliefs.htm

McLaren, P. (2011). Eleştirel pedagojiye giriş. (M. Yunus Eryaman, H. Arslan, Çev.). Ankara: Anı Yayınları.

Mertens, D. M. (2015). Research and evaluation in education and psychology: Integrating diversity with quantitative, qualitative, and mixed methods. Thousand Oaks, CA: Sage.

Mızıkacı, F. ve Gözütok, F. D. (2013). 2005/2009 ilköğretim programı. Gözütok, F. D., Bıkmaz, F., Mızıkacı, F., Şahin, S., Ulubey, Ö., Koçer, E. ve Akçatepe, A. (Ed), Cumhuriyet'in ilanından 2013'e öğretim programlarının analizi: Hayat bilgisi örneği (s. 209-246) içinde. Ankara: Yargı Yayınevi.

National Research Council (NRC). (2012). A framework for K-12 science education: Practices, crosscutting concepts, and core ideas. Washington, DC: The National Academy Press.

Organisation for Economic Co-operation and Development [OECD] (2017, Temmuz). OECD annual raport. [Yıllık rapor], Erişim adresi (17. 07. 2020): https://www.oecd.org/education/skills-beyondschool/EAG2017CN-Turkey-Turkish.pdf

Oliva, P. (1982). Developing the curriculum. Boston: Scott, Foresman and Company.

Ornstein, A. C. ve Hunkins, F. P. (2018). Curriculum: Foundations, principles, and issues. Harlow: Pearson Education.

Ozan, C. ve Köse, E. (2014). Eğitim programları ve öğretim alanındaki araştırma eğilimleri. Sakarya Üniversitesi Journal of Education, 4(1), 116-136.

Özkal, N. (2020). Eğitim programları ve öğretim alanında yapılan doktora tezlerinin incelenmesi: 2015-2019. OPUS-Uluslararası Toplum Araştırmaları Dergisi, 15(25), 3415-3442. doi: 10.26466/opus.647030

Özsoy, S. (2012). Eğitimi politik düşün(eme)mek üzerine bir örnek olay incelemesi: 4x3'lük zorunlu eğitim tartışmaları. Eğitim Bilim Toplum, 10(39), 93-123.

Pinar, W. (2010a). Curriculum theory. C. Kridel (Ed.), Encyclopedia of curriculum studies (s. 267-270) içinde. Thousand Oaks, CA: Sage.

Pinar, W. (2010b). Reconceptualization. C. Kridel (Ed.), Encyclopedia of curriculum studies (s. 735-736) içinde. California: Sage.

Pinar, W. (2013). Curriculum studies in the United States: Present circumstances, intellectual histories. New York: Palgrave Macmillan.

Posner, G. J. (2004). Analyzing the curriculum. New York: McGraw-Hill.

Pratt, D. (1982). A cybernetic model for curriculum development. Instructional Science, 11(1), 1-12. doi: $10.1007 /$ bf00120977

Rogers, E. M. (2003). Diffusion of innovations. New York: Free Press of Glencoe.

Schreglmann, S. (2016). Türkiye'de program geliştirme konusu ile ilgili yapılan yüksek lisans ve doktora tezlerinin içerik analizi. Uluslararası Sosyal Araştırmalar Dergisi, 9(43), 1492-1500. doi: 10.17719/jisr.20164317720

Schubert, W. H. (2010). Curriculum studies, definitions and dimensions. C. Kridel (Ed.), Encyclopedia of curriculum studies (s. 229-237) içinde. Thousand Oaks, CA: Sage.

Schwab, J. J. (1969). The practical: A language for curriculum. The School Review, 78(1), 1-23.

Selçuk, Z., Palancı, M., Kandemir, M. ve Dündar, H. (2014). Eğitim ve Bilim dergisinde yayınlanan araştırmaların eğilimleri: Içcerik analizi. Eğitim ve Bilim, 39(173), 430-453.

Shenton, A. K. (2004). Strategies for ensuring trustworthiness in qualitative research projects. Education for Information, 22, 63-75. 
Sönmez, V. (2019, Aralık). Veysel Sönmez ile söyleşi: Eğitim sorunları ve felsefe üzerine [Blog yazısı]. Erişim adresi (10. 06. 2020): http://www.nirvanasosyal.com/h-408-hasan-gunesin-prof-dr-veysel-sonmezle-egitimsorunlari-ve-felsefesi-uzerine-soylesisi.html

Şahin, A. ve Kumral, O. (2013). Öğretmen adaylarının öğretim programına ve program rollerine ilişkin imgeleri. Akdeniz Eğitim Araştırmaları Dergisi, 14, 19-32.

Şişman, M. (2006, Kasım). Eğitimde demokrasi ve sosyal adalet: Türkiye eğitim sisteminin değişmeyen miti. Türk Eğitim Sisteminde Yeni Paradigma Arayışları Bildiriler Kitabı (s. 291-305) içinde. Ankara: Eğitim Bir-Sen Yayınları.

Tomul, E. (2009). Illköğretim okullarındaki sosyal adalet uygulamalarına ilişkin yönetici görüşleri. Eğitim ve Bilim, 34(152), 126-137.

Valenti, M. ve Campbell, R. (2009). Working with youth on LGBT issues: Why gay-straight alliance advisors become involved. Journal of community psychology, 37(2), 228-248.

Varış, F. (1985). Program geliştirmede metodolojik sorunlar. Ankara Üniversitesi Eğitim Bilimleri Fakültesi Dergisi, 18(1), 67-77.

Varış, F. (1988). Eğitimde program geliştirme: 'Teori ve teknikler'. Ankara: Ankara Üniversitesi Basımevi.

Ventura, A. ve Jang, S. (2010). Private tutoring through the internet: Globalization and offshoring. Asia Pacific Education Review, 11(1), 59-68.

Woodson, A. N. (2015). "What you supposed to know": Urban black students' perspectives on history textbooks. Journal of Urban Learning, Teaching, and Research, 11, 57-65.

Wraga, W. G. (1999). The progressive vision of general education and the American common school ideal: Implications for curriculum policy, practice, and theory. Journal of Curriculum Studies, 31(5), 523-544.

Yeşilpınar Uyar, M. (2017). Eğitim programları ve öğretim alanına yönelik bir dergideki araştırmalara ilişkin içerik analizi: 2002-2015. Kastamonu Eğitim Fakültesi Dergisi, 25(3), 1008-1024.

Yıldırım, A. ve Şimşek, H. (2018). Sosyal bilimlerde nitel araştırma yöntemleri. Ankara: Seçkin Yayınevi.

\section{Çalışmada İncelenen Araştırmaların Listesi}

Akbulut, N. ve Aslan, S. (2016). Örtük program ölçeği geliştirme çalışması. Elektronik Sosyal Bilimler Dergisi, 15(56), 169-176.

Akrom, M. A. (2015). The mirage of curriculum decentralization: A case study of local stakeholders' involvement in school-based curriculum development (SBCD) policy implementation in Indonesia (Doktora tezi). ProQuest Dissertations and Theses veri tabanından erişildi. (UMI No. 3707077).

Anwaruddin, M. S. (2017). Emotions in the curriculum of migrant and refugee students. Curriculum Inquiry, 47(1), 112-124. doi: 10.1080/03626784.2016.1255936

Arsal, Z. (2014). İlköğretim fen ve teknoloji dersi öğretim programı kazanımlarının yapılandırmacılık ilkelerine göre değerlendirilmesi. International Journal of Curriculum and Instructional Studies, 2(3), 1-14.

Bajaj, M. ve Bartlett, L. (2017). Critical transnational curriculum for immigrant and refugee students. Curriculum Inquiry, 47(1), 25-35. doi: 10.1080/03626784.2016.1254499

Bay, E., Vural, Ö. F., Kahramanoğlu, R. ve Aydın Aşk, Z. (2016). Teacher views on school-based curriculum development approach (an analysis of applicability in Turkey). Mustafa Kemal Üniversitesi Sosyal Bilimler Enstitüsü Dergisi, 13(34), 180-201.

Bolat, Y. (2017). Eğitim programı okuryazarlığı kavramı ve eğitim programı okuryazarlığı ölçeği. Turkish Studies, 12(18), 121-138. doi: 10.7827/TurkishStudies.12103

Boztaş, K. (2015). Tutum ve değerler kapsamında polis meslek yüksekokulu örtük programı (Yayımlanmamış doktora tezi). Balıkesir Üniversitesi, Balıkesir.

Bray, M. Kobakhidze, M. N., Zhang, W. ve Liu, J. (2018). The hidden curriculum in a hidden marketplace: Relationships and values in Cambodia's shadow education system. Journal of Curriculum Studies, 50(4), 435-455. doi: 10.1080/00220272.2018.1461932

Bryan, A. (2012). 'You've got to teach people that racism is wrong and then they won't be racist': Curricular representations and young people's understandings of 'race' and racism. Journal of Curriculum Studies, 44(5), 599-629. doi: 10.1080/00220272.2012.699557

Burti, N., Jr. (2010). Curricula alignment and its impact on end of course assessment scores (Doktora tezi). ProQuest Dissertations and Theses veri tabanından erişildi. (UMI No. 3439084). 
Bümen, N.T., Çakar, E. ve Yıldız, D. G. (2014). Türkiye'de öğretim programına bağlılık ve bağlılığı etkileyen etkenler. Kuram ve Uygulamada Eğitim Bilimleri, 14(1), 203-228.

Çapuk, S. (2014). Türkiye ve ABD'de yürürlükte olan "eğitim programları ve öğretim" alanındaki yüksek lisans ve doktora programlarının karşılaştırmalı olarak incelenmesi (Yayımlanmamış doktora tezi). İnönü Üniversitesi, Malatya.

Çengel, M. ve Türkoğlu, A. (2016). Analysis through hidden curriculum of peer relations in two different classes with positive and negative classroom climates. Educational sciences: Theory \& practice, 16(6), 18931919.

De Leon R, V. (2019). The inflexibility of flexible curriculum: A critical discourse analysis of aceleración del aprendizaje (Doktora tezi). ProQuest Dissertations and Theses veri tabanından erişildi. (UMI No. 13903067).

Demiralp, N. (2017). Coğrafya öğretiminde programların tasarım ve program öğeleri açısından incelenmesi ve 2017 öğretim programı. 21. Yüzyılda Eğitim ve Toplum Eğitim Bilimleri ve Sosyal Araştırmalar Dergisi, 6(17), 521-545.

Desai, K. (2016). Teaching the third world girl: Girl rising as a precarious curriculum of empathy. Curriculum Inquiry, 46(3), 248-264. doi: 10.1080/03626784.2016.1173510

Dikbayır, A. (2018). Tasarlanan, uygulanan ve ölçülen lise matematik programlarındaki uyumun incelenmesi (Yayımlanmamış doktora tezi). Ege Üniversitesi, İzmir.

Dikbayır, A. ve Bümen, N. (2016). Dokuzuncu sınıf matematik dersi öğretim programına bağıılı̆̆ın incelenmesi. Uluslararası Eğitim Programları ve Öğretim Çalışmaları Dergisi, 6(11), 17-38.

Dixon Mclnerney, S. A. (2019). A study of curriculum customization in the era of standardization of education (Doktora tezi). ProQuest Dissertations and Theses veri tabanından erişildi. (UMI No. 22624440).

Donald-Whitney, C. (2019). Perceptions of curriculum quality management in a multicampus community college district (Doktora tezi). ProQuest Dissertations and Theses veri tabanından erişildi. (UMI No. 27672581).

Dutro, E. ve Selland, M. (2012). "I like to read, but I know I'm not good at it": Children's perspectives on highstakes testing in a high-poverty school. Curriculum Inquiry, 42(3), 340-367. doi: 10.1111/j.1467873X.2012.00597.x

Erginer, E. ve Örten, D. (2010). Türkiye'de eğitimde program geliştirme alanındaki öncü akademisyenlerin eğitimde program geliştirmeye ilişkin metaforik algıları. OPUS Uluslararası Toplum Araştırmaları Dergisi, 6(11), 387-414.

Erss, M., Kalmus, V. ve Autio, T. H. (2016). 'Walking a fine line': Teachers' perception of curricular autonomy in Estonia, Finland and Germany. Journal of Curriculum Studies, 48(5), 589-609. doi: 10.1080/00220272.2016.1167960

Fahey, S. (2012). Curriculum change and climate change: Inside outside pressures in higher education. Journal of Curriculum Studies, 44(5), 703-722. doi: 10.1080/00220272.2012.679011

Fenwick L. (2012). Limiting opportunities to learn in upper-secondary schooling: Differentiation and performance assessment in the context of standards-based curriculum reform. Curriculum Inquiry, 42(5). 629-651. doi: 10.1111/j.1467-873X.2012.00609.x

Filiz, S. B. ve Baysal, S. B. (2019). Sosyal bilgiler dersi öğretim programı kazanımlarının revize edilmiş Bloom taksonomisine göre analizi. Inönü Üniversitesi Eğitim Fakültesi Dergisi, 20(1), 234-253.

Gacoin, E., A. (2016) Who am I? Identity and the facilitation of local youth lives within sexuality education as an HIV prevention strategy. Curriculum Inquiry, 46(4), 408-426. doi: 10.1080/03626784.2016.1205941

Garrett, H. J. (2020). Containing classroom discussions of current social and political issues. Journal of Curriculum Studies, 52(3), 337-355. doi: 10.1080/00220272.2020.1727020

Guo, S. ve Maitra, S. (2017). Revisioning curriculum in the age of transnational mobility: Towards a transnational and transcultural framework. Curriculum Inquiry, 47(1), 80-91. doi: 10.1080/03626784.2016.1254504

Hakwoort, I. ve Olsson, E. (2014). The school's democratic mission and conflict resolution: Voices of Swedish educators. Curriculum Inquiry, 44(4), 531-552. doi: 10.1111/ curi.12059

Hedges, H., Cullen, J. ve Jordan, B. (2011). Early years curriculum: Funds of knowledge as a conceptual framework for children's interests. Journal of Curriculum Studies, 43(2), 185205. doi: 10.1080/00220272.2010.511275

Hong, W. ve Halvorsen, A. L. (2010). Teaching Asia in US secondary school classrooms: A curriculum of othering. Journal of Curriculum Studies, 42(3), 371-393. doi: 10.1080/00220270903353269

Ito M., Soep, E., Kligler-Vilenchik, N., Shresthova, S., Gamber-Thompson, L. ve Zimmerman, A. (2015). Learning connected civics: Narratives, practices, infrastructures. Curriculum Inquiry, 45(1), 1029. doi: 10.1080/03626784.2014.995063 
Ivens, J. P. (2018). Making the modern person: The tyler rationale, curriculum studies, and cybernetic systems (Doktora tezi). ProQuest Dissertations and Theses veri tabanından erişildi. (UMI No. 10830471).

İşeri, A. (2011). Program teorisinin düşünsel temelleri: Felsefe, sosyoloji ve ideoloji kuramları açısından (Yayımlanmamış doktora tezi). Abant İzzet Baysal Üniversitesi, Bolu.

Jang, S. B. (2017). Centralized curriculum control discourses: The case of South Korea (Doktora tezi). ProQuest Dissertations and Theses veri tabanından erişildi. (UMI No. 10278333).

Jarratt, L. (2020). Bordering the other, building the nation-state: Positioning the refugee as a subject of school knowledge. Journal of Curriculum Studies, 52(3), 356-371. doi: 10.1080/00220272.2019.1695147

Jarvis, H. D. (2012). Case studies in leadership and curriculum change (Doktora tezi). ProQuest Dissertations and Theses veri tabanından erişildi. (UMI No. 3524734).

Kahramanoğlu, R. (2019). Öğretmenlerin öğretim programı okuryazarlığına yönelik yeterlik düzeyleri üzerine bir inceleme. Journal of International Social Research, 12(65), 827-840.

Karaman, P. ve Bakaç, E. (2018). Öğretmenlerin eğitim programı yaklaşımı tercihlerinin çeşitli değişkenler açısından incelenmesi. Abant İzzet Baysal Üniversitesi Eğitim Fakültesi Dergisi, 18(1), 304-320.

Kaya, E., Çetin, P. S. ve Yıldırım, A. (2012). Transformation of centralized curriculum into classroom practice: An analysis of teachers' experiences. International Journal of Curriculum and Instructional Studies, 2(3), 103-114.

Keller, D. J. (2015). International education curriculum: Stakeholder values and perspectives (Yayımlanmamış doktora tezi). İhsan Doğramacı Bilkent Üniversitesi, Ankara.

Korkmaz, F. (2016). Yeniden kavramsallaştırmacılık akımı bağlamında 6.sınıf sosyal bilgiler dersi öğretim programının politik bir metin olarak incelenmesi (Yayımlanmamış doktora tezi). Gaziantep Üniversitesi, Gaziantep.

Kürüm Yapıcıoğlu, D., Atik Kara, D. ve Sever, D. (2016). Türkiye'de program değerlendirme çalışmalarında eğilimler ve sorunlar: Alan uzmanlarının gözüyle. International Journal of Curriculum and Instructional Studies, 6(12), 91-113.

Limes, K. ve Henderson, T. (2019). "I had never been at home in the world" 1: A case for black-indigenism. Curriculum Inquiry, 49(1), 44-64. doi: 10.1080/03626784.2018.1556562

Mala, N. (2011). Cumhuriyetten günümüze ilköğretim programlarının faydacı ve ilerlemeci ekole uygunluğu bakımından değerlendirilmesi (Yayımlanmamış doktora tezi). İnönü Üniversitesi, Malatya.

Mansoor A. ve Malik, S. (2016). Deconstructive pedagogy and ideological demystification in post-colonial Pakistan. Curriculum Inquiry, 46(5), 491-509. doi: 10.1080/03626784.2016.1236655

Martino, W. ve Potvin, W. C. (2011). “They didn't have out there gay parents-they just looked like normal regular parents": Investigating teachers' approaches to addressing same-sex parenting and non-normative sexuality in the elementary school classroom. Curriculum Inquiry, 41(4), 480-501. doi: 10.1111/j.1467873X.2011.00557

Mathou, C. (2018). Recontextualizing curriculum policies: A comparative perspective on the work of mid-level actors in France and Quebec. Journal of Curriculum Studies, 50(6), 789-804. doi: 10.1080/00220272.2018.1513567

Mızıkacı, F., Göktunalı, Ö., Aktaş, A. K., Görür, D. Z., Kızıl, F. ve Çınar, S. (2019). Üniversite lisans ders programlarının süreç ve sonuç odaklı program geliştirme yaklaşımlarına göre öğrenci görüşleri açısından incelenmesi. Hacettepe Üniversitesi Eğitim Fakültesi Dergisi, 34(4), 943-957.

Mølstad, C. E. (2015). State-based curriculum-making: Approaches to local curriculum work in Norway and Finland. Journal of Curriculum Studies, 47(4), 441-461. doi: 10.1080/00220272.2015.1039067

Moroye, C. M. ve Ingman, C. B. (2013). Ecological mindedness across the curriculum. Curriculum Inquiry, 43(5), 588-612. doi: 10.1111/curi.12028

Nieto, D. ve Bickmore, K. (2017). Immigration and emigration: Canadian and Mexican youth making sense of a globalized conflict. Curriculum Inquiry, 47(1), 36-49. doi: 10.1080/03626784.2016.1255934

Osmond-Johnson, P. ve Turner, T. (2020). Navigating the "ethical space" of truth and reconciliation: NonIndigenous school principals in Saskatchewan. Curriculum Inquiry, 50(1), 54-77. doi: 10.1080/03626784.2020.1715205

Özer, B. ve Alkan, S. (2017). AB ve Türkiye öğretmen yetiştirme programlarının karşılaştırılması ve Türkiye için bir model önerisi. Disiplinlerarası Eğitim Araştırmaları Dergisi, 1(1), 62-95.

Özkan, U. B. (2018). Tek parti döneminde hazırlanan parti programları temelinde eğitimin uzak hedefleri. Balıkesir Üniversitesi Sosyal Bilimler Enstitüsü Dergisi, 21(39), 183-206. 
Özyurt, M., Demir, S. ve Bay, E. (2015). Okul temelli yaklaşımla geliştirilen değer eğitim programının etkililiğinin değerlendirilmesi. Ege Eğitim Dergisi, 16(2), 274-296.

Pantić, N. ve Wubbels, T. (2012). Competence-based teacher education: A change from didaktik to curriculum culture?.Journal of Curriculum Studies, 44(1), 61-87. doi: 10.1080/00220272.2011.620633

Pennell, S. M. (2016). Queering the curriculum: Critical literacy and numeracy for social justice (Doktora tezi). ProQuest Dissertations and Theses veri tabanından erişildi. (UMI No. 10119771).

Rombalski, A. (2020). I believe that we will win! Learning from youth activist pedagogies. Curriculum Inquiry, 50(1), 28-53. doi: 10.1080/03626784.2020.1749515

Scholtz, D. (2020). Qualifications development for an unknown future. Journal of Curriculum Studies, 52(3), 413427. doi: 10.1080/00220272.2019.1689430

Salter, S. (2014). Teachers' cultural maps: Asia as a "tricky sort of subject matter". Curriculum Inquiry, 44(2), 204227. doi: $10.1111 /$ curi.12043

Skelton, C. ve Francis, B. (2011). Successful boys and literacy: Are "literate boys" challenging or repackaging hegemonic masculinity? Curriculum Inquiry, 41(4), 456-479. doi: 10.1111/j.1467-873X.2011.00559.x

Selvi, K., Uysal, D., Polat, M., Sönmez, T., Köse, C. ve Yetim, N. (2016). SUPSKY curriculum design model. Uluslararası Eğitim Programları ve Öğretim Çalışmaları Dergisi, 6(12), 33-56.

Serhatlıoğlu, B. (2012). Sosyal becerilerin kazanımı sürecinde örtük programın işlevi (Yayımlanmamış doktora tezi). Fırat Üniversitesi, Elazığ.

Sonu, D. (2016). Forgotten memories of a social justice education: Difficult knowledge and the impossibilities of school and research. Curriculum Inquiry, 46(5), 473-490. doi: 10.1080/03626784.2016.1236657

Stiegler, S. (2016). Privacy for all students? Talking about and around trans students in "public". Curriculum Inquiry, 46(4), 348-368. doi: 10.1080/03626784.2016.1209638

Şahin, Ş., Ökmen, B., Boyacı, Z., Kılıç, A. ve Adıgüzel, A. (2018). Eğitim programları ve öğretim yüksek lisans programı ihtiyaç analizi. Journal of Higher Education \& Science, 12(3), 502-511.

Şiraz, F. (2020). Politik bir metin olarak sosyal bilgiler öğretim programlarını vatandaşlık eğitimi bağlamında anlama (Yayımlanmamış doktora tezi). Gaziantep Üniversitesi, Gaziantep.

Tatar, ş. (2019). Ihmal edilen eğitim programında tartışmalı konuların ilk ve ortaokul öğretim programları bağlamında incelenmesi (Yayımlanmamış doktora tezi). Anadolu Üniversitesi, Eskişehir.

Thomas, R. (2019). Identifying your skin is too dark as a put-down: Enacting whiteness as hidden curriculum through a bullying prevention programme. Curriculum Inquiry, 49(5), 573-592. doi: 10.1080/03626784.2019.1687258

Thompson, M. J. (2019). An inquiry into the internationally minded curriculum (Doktora tezi). ProQuest Dissertations and Theses veri tabanından erişildi. (UMI No. 22616176).

Tokgöz, Ö. (2013). Transformation of centralized curriculum into teaching and learning processes: Teachers' journey of thought curriculum into enacted one (Yayımlanmamış doktora tezi). Orta Doğu Teknik Üniversitesi, Ankara.

Toledo, W. (2020). Civically minded: The types of knowledge teachers use to adapt a civics curriculum. Journal of Curriculum Studies, 52(1), 64-83. doi: 10.1080/00220272.2019.1650118

Tuncel, ì. ve Demirel, Ö. (2018). Değerlendirme sürecinin örtük program açısından incelenmesi. Pamukkale Üniversitesi Sosyal Bilimler Enstitüsü Dergisi, 31(1), 220-230.

Ünver, G. ve Erdamar, G. (2015). Türkiye'de erken çocukluk dönemi öğretmenlerinin eğitim programı geliştirme sürecine katkıları. Journal of Kirsehir Education Faculty, 16(1), 215-234.

Welker, R. W. ve Mohr, K. M. (2017). The role of integrated curriculum in the 21st century school (Doktora tezi). ProQuest Dissertations and Theses veri tabanından erişildi. (UMI No. 10604384).

Whitaker, S. (2012). Planning and implementing a global curriculum: A case study of one North Carolina elementary school (Doktora tezi). ProQuest Dissertations and Theses veri tabanından erişildi. (UMI No.3526735).

Wu, J. (2012). Governing suzhi and curriculum reform in rural ethnic China: Viewpoints from the miao and dong communities in Qiandongnan. Curriculum Inquiry, 42(5), 652-681. doi: 10.1111/j.1467873X.2012.00611.x

Yang, W. ve Li, H. (2018a). Cultural ideology matters in early childhood curriculum innovations: A comparative case study of Chinese kindergartens between Hong Kong and Shenzhen. Journal of Curriculum Studies, 50(4), 560-585. doi: 10.1080/00220272.2018.1428367

Yang, W. ve Li, H. (2018b). A school-based fusion of East and West: A case study of modern curriculum innovations in a Chinese kindergarten. Journal of Curriculum Studies, 50(1), 1737. doi: 10.1080/00220272.2017.1294710 
Yazçayır, N. (2016). DAPDEM öğretim programı değerlendirme ölçütlerinin geliştirilmesi. Uluslararası Eğitim Programları ve Öğretim Çalışmaları Dergisi, 6(12), 169-186.

Yazçayır, N., Selvi, K. ve Demirel, Ö. (2013). Türkiye'de genel ortaöğretim programlarının değerlendirilmesi. Uluslararası Eğitim Programları ve Öğretim Çalışmaları Dergisi, 3(5), 13-24.

Yeşilyurt, E. (2019). Güncellenen öğretim programları bağlamında okul yöneticilerinin program liderliğinin değerlendirilmesi. Journal of International Social Research, 12(62), 1119-1142.

Yıldırım, F. (2013). Ilköğretim okullarında örtük program ve ilköğretim öğrencilerinin örtük programdan kaynaklanan stres algıları (Yayımlanmamış doktora tezi). Fırat Üniversitesi, Elazı̆̆.

Yoon, E. S. (2016). Neoliberal imaginary, school choice, and "new elites" in public secondary schools. Curriculum Inquiry, 46(4), 369-387. doi: 10.1080/03626784.2016.1209637

Yurdakul, B. (2015). Perceptions of elementary school teachers concerning the concept of curriculum. Educational Sciences: Theory and Practice, 15(1), 125-139.

Yücel, E., Dimici, K., Yıldız, B. ve Bümen, N. T. (2017). An analysis of the primary and secondary school English language curricula published over the last 15 years. Ege Journal of Education, 18(2), 702-737.

Yüksel, i. (2010). Türkiye için program değerlendirme standartları oluşturma çalışması (Yayımlanmamış doktora tezi). Anadolu Üniversitesi, Eskişehir.

Zhao W. (2020). Problematizing “epistemicide" in transnational curriculum knowledge production: China'suyang curriculum reform as an example. Curriculum Inquiry, 50(2), 105-125. doi: 10.1080/03626784.2020.1736521 